\title{
CLIMATE CHANGE IMPACTS ON BIODIVERSITY AND ECOSYSTEMS IN SRI LANKA: A REVIEW
}

\author{
J. Dananjaya Kottawa-Arachchi, Madawala A. Wijeratne \\ Tea Research Institute of Sri Lanka, Sri Lanka \\ e-mail:jeevan1188@yahoo.com,jeevank@tri.lk
}

Received: 02.08.2017

\begin{abstract}
The climate change impacts are felt by all facets and sectors of ecosystems, covering flora, fauna and environment. Sri Lanka is considered as a vulnerable, small island country that is under serious threat from climate change impacts. The most profound impacts of climate change in Sri Lanka will be on agriculture and food security, water and coastal resources, biodiversity changes, and human health. Sri Lanka's biodiversity is significantly important both on a regional and global scale as it has the highest species density for flowering plants, amphibians, reptiles, and mammals. Sri Lanka's varied ecosystems provide many services that are of significant economic value and play a crucial role in providing goods and ecosystem services. The subsequent sections featuring specific aspects of biodiversity in forests, freshwater wetlands, coastal and marine systems and agricultural systems, provide greater detail on the ecosystem services and bio-resources. Habitat loss and fragmentation, invasive alien species, deforestation and forest degradation, development projects, environmental pollutions and climate change (global warming) are the major threats to the biodiversity of the country. Climate change impacts on environment lead to a reduction in the distribution and abundance of species, especially endemics, which may even result in their global extinction. The introduction of various policies and guidelines in relation to environment is a good sign for conservation of ecosystems and biodiversity. The government of Sri Lanka has been implementing various environmental projects aiming at reducing deforestation and degradation of ecosystems. Policies and measures already developed under such initiatives will no doubt preserve natural habitats for plant and animal species. However, being a developing country with many economic challenges, the funds and expertise available for monitoring climate change impacts and biodiversity conservation are not sufficient.
\end{abstract}

Key words: agriculture, central highlands, drought, flood, loss of species, lowland rainforest, rainfall, threatened species

\section{Introduction}

Living and non-living organisms, their ecosystems and climatic conditions can be considered as dependent components of the world and their balance is essential for the existence of the world (Khaine \& Woo, 2015). Climate change is a significant and lasting change in the statistical distribution of weather patterns over periods ranging from decades to millions of years. The major drivers of climate change can be divided into two types i.e. anthropogenic causes such as land use changes, deforestation and forest degradation, fossil fuel burning and industrial processes, and natural causes such as solar radiation changes and volcanic activity (IPCC, 2013). Such anthropogenic activities are reported to emit greenhouse gases $\left(\mathrm{CO}_{2}, \mathrm{CH}_{4}\right.$, $\mathrm{N}_{2} \mathrm{O}, \mathrm{O}_{3}, \mathrm{CFCs}$ ) which contribute to a rise in the atmospheric temperature (global warming).
In general, climate change means a change of climate that is attributed directly or indirectly to human activity that alters the composition of the global atmosphere and which is in addition to the natural climate variability observed over comparable time periods (UNFCC, 1992). The major concerns with the projected change in climate are increases in ambient temperatures, sea level and extreme weather events. In recent years, recurrence of extreme weather events such as hurricanes, severe cyclonic storms, floods, droughts, heat waves and cold spans have increased in many parts of the world. These extreme climatic events could have profound impacts on life on earth, the natural environment and the world economy (Easterling et al., 2000).

Predicting climate change impacts on global biodiversity is an extremely active field of research. In recent years, many studies have 
investigated the effects of climate change on biodiversity and ecosystems (Mcmahon et al., 2011; Bellard et al., 2012). Several studies suggest that climate change could worsen habitat destruction as the greatest global threat to biodiversity over the next few decades (Dawson et al., 2011). The major concern of the climate change impacts is decreasing genetic diversity of a population due to directional selection and rapid migration. It could also affect ecosystem functioning and resilience (Botkin et al., 2007).

Sri Lanka is considered as a vulnerable, small island country that is under serious threat from various climate change impacts (MOE, 2010) such as droughts, heavy rainfall events with floods, high and low temperatures, lightning and destructive winds (Premalal \& Punyawardena, 2013). The rainfall pattern is of primary significance in defining the island's climate (MOE, 2011). Recent studies have revealed declining rainfalls and increasing trends in extreme temperatures in Sri Lanka (de Costa, 2008; MOE, 2011; Wijeratne \& Chandrapala, 2013; Zubair etal., 2016). Changes in precipitation indices in Sri Lanka showed stronger decreasing trends compared with other regions (Sheikh et al., 2014). The variability of rainfall in Sri Lanka has also been increased, disrupting the normal weather pattern. Accordingly, the most profound impacts of climate change in Sri Lanka will be on agriculture and food security, water and coastal resources, biodiversity changes, and human health.

\section{Status of Biodiversity and ecosystems in Sri Lanka}

Sri Lanka, with a total land area of $65,610 \mathrm{~km}^{2}$ is a tropical island situated in the Indian Ocean. The Western Ghats in India and Sri Lanka is treated as a global biodiversity hotspot, in demand of extensive conservation investment (Myers et al., 2000). Sri Lanka's rich and unique biodiversity forms the basis for the country's natural heritage, and is a core feature of its cultural heritage and economic advancement. This high biodiversity seen in Sri Lanka can be attributed due to a wide variety of climatic, topographic (Fig. 1) and soil conditions on the island which has resulted in a diverse array of aquatic and terrestrial habitats. Sri Lanka's biodiversity is significantly important both on a regional and global scale as it has the highest species density for flowering plants, amphibians, reptiles, and mammals in the Asian region (MOE, 2012).

Sri Lanka has a rich diversity in lower plants and invertebrates. According to floristic endemism records, nearly $70 \%$ of evergreen trees, $40 \%$ of lianas and $11 \%$ of mosses are endemic to the country (Gunawardene et al., 2007). The faunal diversity in the Sri Lankan forests is quite outstanding. Some taxa are confined or restricted to one or a few locations, either in the Rakwana-Deniyaya hills, Central Highlands or the Knuckles (Gunatilleke et al., 2008). Sri Lanka is notably one of the richest countries for amphibian diversity with 3.9 species per $1000 \mathrm{~km}^{2}$ (MOE, 2010). The majority of the endemic and threatened amphibians are confined to the wet zone and especially to the montane ecosystem. Among the selected groups of inland invertebrate fauna evaluated, the highest number of threatened species was recorded among the land snails, followed by bees, butterflies, spiders, dragonflies, ants and freshwater crabs (MOE, 2012). Some of the selected taxonomic groups are shown in the Table 1.

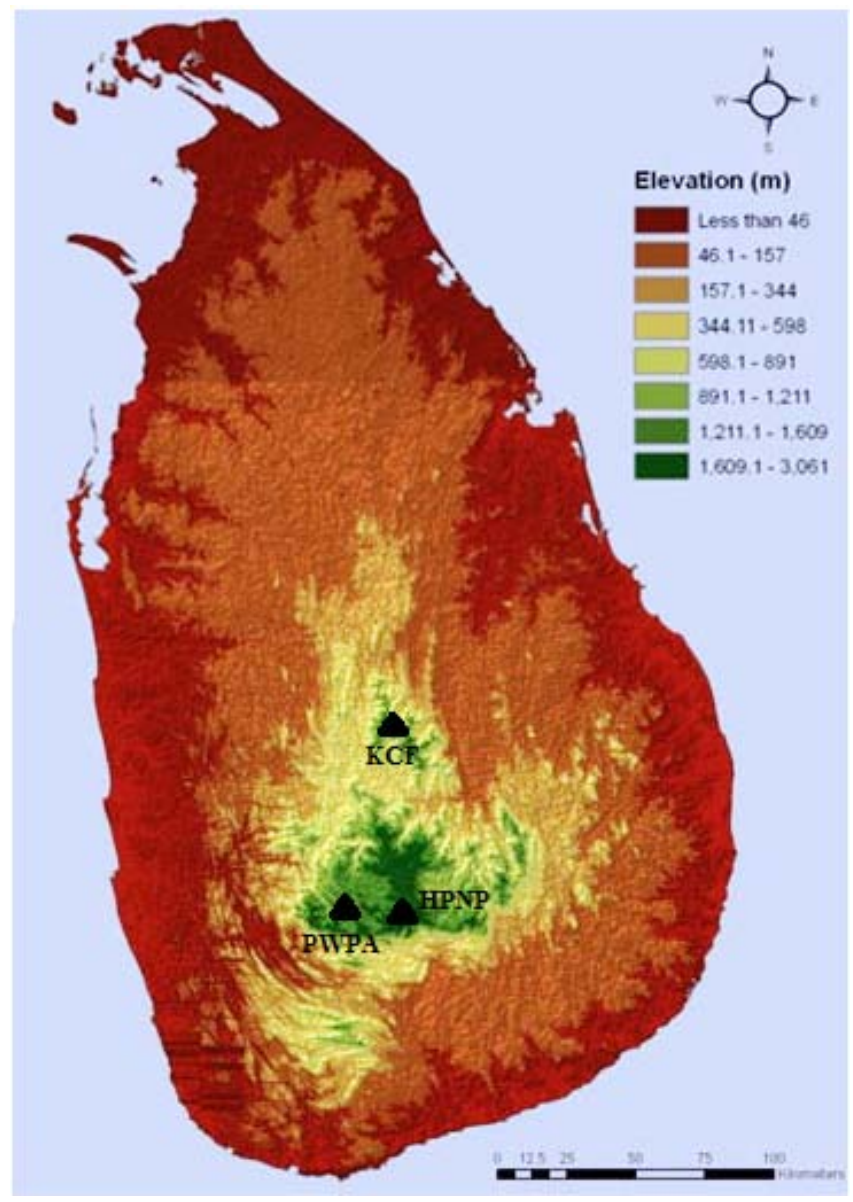

Fig. 1. Altitudinal variation in Sri Lanka. Source: (MOE, 2010). Abbreviations: PWPA: Peak Wilderness Protected Area, HPNP: Horton Plains National Park, KCF: Knuckles Conservation Forest. 
Table 1. Nationally threatened fauna of Sri Lanka from selected taxonomic group

\begin{tabular}{|l|c|c|c|c|c|}
\hline \multicolumn{1}{|c|}{ Taxonomic group } & $\begin{array}{c}\text { Number of species } \\
\text { recorded }\end{array}$ & $\begin{array}{c}\text { Critically } \\
\text { Endangered }\end{array}$ & Endangered & Vulnerable & $\begin{array}{c}\text { Near } \\
\text { Threatened }\end{array}$ \\
\hline Land snails & $253(205)$ & $76(66)$ & $66(62)$ & $23(20)$ & $7(5)$ \\
\hline Freshwater crabs & $51(50)$ & $34(34)$ & $12(11)$ & & $5(5)$ \\
\hline Dragonflies & $118(47)$ & $26(21)$ & $18(14)$ & $17(4)$ & $17(1)$ \\
\hline Butterflies & $245(26)$ & $20(3)$ & $40(10)$ & $36(8)$ & 21 \\
\hline Freshwater fishes & $91(50)$ & $19(16)$ & $19(17)$ & $5(4)$ & $5(3)$ \\
\hline Amphibians & $111(95)$ & $34(34)$ & $28(27)$ & $10(9)$ & $3(3)$ \\
\hline Reptiles & $210(126)$ & $38(36)$ & $51(40)$ & $18(11)$ & $15(7)$ \\
\hline Resident birds & $237(27)$ & 6 & $18(7)$ & $30(9)$ & $35(3)$ \\
\hline Mammals & $124(21)$ & $13(4)$ & $24(8)$ & $16(3)$ & $9(1)$ \\
\hline
\end{tabular}

Source: The National Red List 2012 of Sri Lanka (Bahir \& Gabadage, 2012); Conservation Status of the Fauna and Flora (MOE, 2012). The number of endemic species is given within brackets.

The central highland complex of Sri Lanka is situated in the South-central part of the island and comprises of the Peak Wilderness Protected Area (PWPA), the Horton Plains National Park (HPNP) and the Knuckles Conservation Forest (KCF). These montane forests, where the land rises up to $2500 \mathrm{~m}$ (above mean sea level), are home to an extraordinary range of flora and fauna. The region is considered as a super biodiversity hotspot (UNESCO, 2010). Given the number of endemics and threatened species, with their restricted distribution, the Central Highlands Complex including Peak Wilderness Protected Area, Horton Plains National Park and Knuckles Conservation Forest were declared as World Heritage Sites by UNESCO in 2010.

The distribution of Sri Lanka's different types of ecosystems (Table 2) depends largely on the spatial variation of rainfall and temperature on the island, as well as on topographic variation and the spatial distribution and diversity of soils (MOE, 2010). Sri Lanka's varied ecosystems provide many services that are of significant economic value and play a crucial role in providing goods and services to meet local and national needs. The subsequent sections featuring specific aspects of biodiversity in forests, freshwater wetlands, coastal and marine systems, and agricultural systems, provide greater detail on the ecosystem services and bio-resources.

Forests in Sri Lanka also play a pivotal role in supporting and regulating ecosystem services. Among those are soil conservation, reducing flood hazards, watershed functions, trapping moisture through fog interception and carbon sequestration. Forests also continue to provide a range of essential goods and services and support livelihoods of people, especially in the rural areas of the dry and intermediate zones. Especially, firewood, medicinal plants, food items and some timber wood requirements from adjacent forests are valuable services to villagers. Forests, waterfalls and streams also play a major role in eco-tourism in Sri Lanka.

Table 2. Ecosystem diversity and their extent in Sri Lanka

\begin{tabular}{lr}
\hline Ecosystems & Extent $\mathbf{( k m}^{\mathbf{2}} \mathbf{~}$ \\
\hline & \\
Sea grass beds & 238.19 \\
Salt marshes & 335.73 \\
Mangroves & 121.89 \\
Lagoons and estuaries & 1580.17 \\
Sand dunes & 76.06
\end{tabular}

\section{Inland aquatic systems}

Fresh water marshes

Rivers and riverine forests

Reservoirs

\section{Natural forests and grasslands}

Lowland rain forests

1233.02

Moist monsoon forest

1178.85

Dry monsoon forests

11213.92

Montane forests

447.85

Sub-montane forests

Savanah grasslands

Open and sparse forest

4294.84

Source: (Gunatilleke et al., 2008; Edirisinghe et al., 2012) 
Falling under the tropical region, the Sri Lankan dense forest consists of different forest types such as lowland rain forests (Fig. 2), dry monsoon forest, montane forests, sub mountain forests and moist monsoon forest (Edirisinghe et al., 2012). The total natural forest cover of Sri Lanka is estimated at $19,514.73 \mathrm{~km}^{2}$, of which $14,382.75 \mathrm{~km}^{2}$ are dense forests (Edirisinghe et al., 2012; MOMDE, 2017). The species composition and structure of the forest vary with the forest type. Table 2 shows the diversity of the different ecosystems in Sri Lanka and their extents. In addition, there are other man-made ecosystems such as agro-ecosystems including agroforestry systems, home gardens and crop plantations.

Agroforestry systems play an important role in preserving the environment and providing economic and environmental benefits. Agriculture is one of the important sectors of the country assuring a sustainable supply of food. Agricultural plant diversity on the island includes Oryza sativa L. (rice / paddy) with improved varieties/land races (Fig. 3), cultivars of maize and sorghum; grain legume species; root and tuber crop species and other vegetables (Gunatilleke et al., 2008). Major plantation crops, covering a large extent in Sri Lanka are tea, rubber, coconut and sugarcane. Cinnamon, pepper, cardamom, coffee, cocoa and arecanut plantations are considered as minor-export crop species. Mixed cropping systems with different perennial crops listed above, having varying heights of canopies and flowering patterns, can be considered as sustainable agro-forestry systems, enriched with biodiversity. A large number of endemic and introduced fruit crop species grown in different climatic regions also helps enhancing the biodiversity in Sri Lanka.

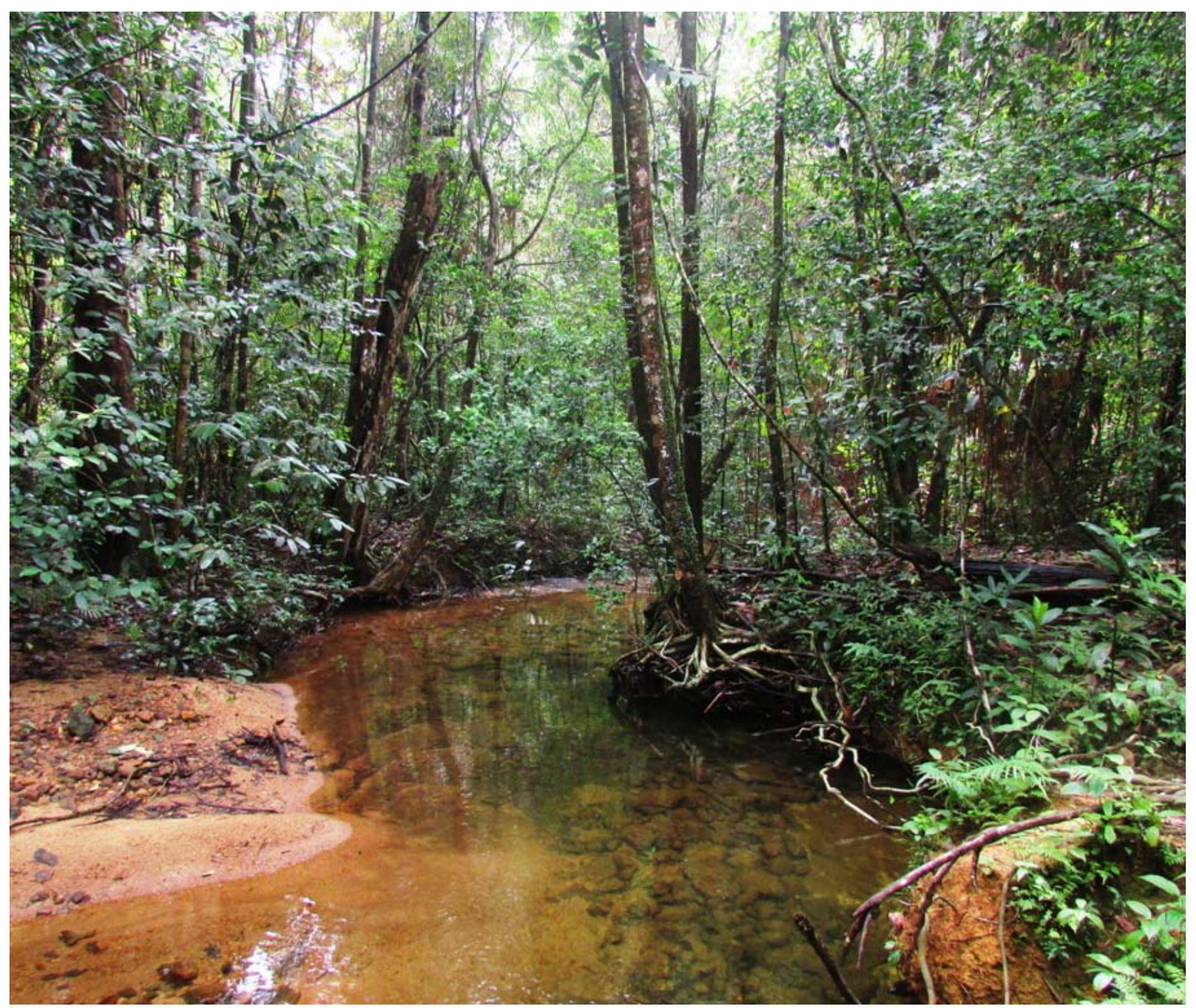

Fig. 2. Lowland rain forest. 


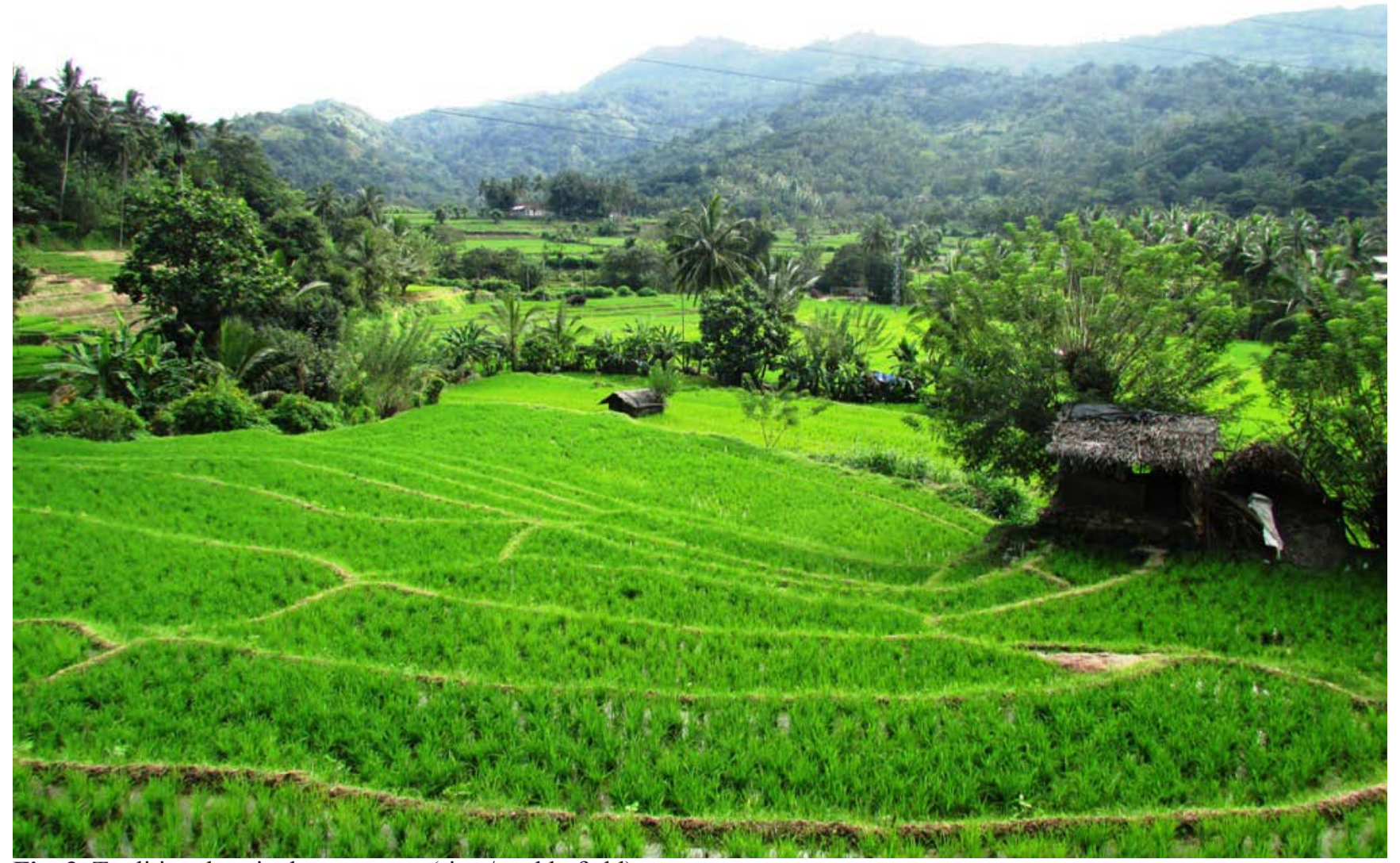

Fig. 3. Traditional agriculture system (rice / paddy field).

Several studies have determined the effects of a human-dominated landscape such as agroforestry and forestry's plantation system on fauna, highlighting the importance of habitat characteristics in sustaining high diversity (Ficetola \& Bernardi, 2004). Agroforestry systems such as plantations of coffee (Greenberg et al., 1997), cacao (Wanger et al., 2009), rubber (Aratrakorn et al., 2005) and oil palm (Gallmetzer \& Schulze, 2015) support a greater number of selected faunal groups with a higher diversity, compared to open agricultural systems in the tropical region. In Sri Lanka, limited biodiversity studies have been conducted with selected taxa in monoculture plantations (Kottawa-Arachchi et al., 2015b).

Homegardens in Sri Lanka are dynamic sustainable food production systems, and presumably the oldest land use activity, next to shifting chena cultivation. Homegardens, have been considered as an important land use system for Sri Lanka in terms of percentage of land area occupied, timber and fuel wood production, and food and nutritional security of the household (Pushpakumara et al., 2012). The homegarden system provides key ecosystem services that may be conceptualised as provisioning, regulating, cultural, and supporting services. In addition, homegardens serve as a habitat for a large range of flora and fauna and thus help in biodiversity conservation (Pushpakumara et al., 2012). A recent study revealed that the highest number of animal species, including threatened species, have been recorded in the homegarden habitat in the tea plantation ecosystem (Fig. 4), concluding that it is an important habitat for sustainable animal life such as herpetofauna and birds (Kottawa-Arachchi \& Gamage, 2015a; Kottawa-Arachchi et al., 2015b).

Wetland ecosystems are amongst the most productive ecosystems that support many kinds of life. They are valuable in terms of hydrology, plant and animal survival, and biodiversity (Kotagama \& Bambaradeniya, 2006). Wetlands, both natural and man-made, currently make up about $15 \%$ of the total land area of Sri Lanka (Dela, 2009). The natural wetlands comprise rivers, streams, riverine floodplains, small isolated freshwater bodies, freshwater springs, seasonal ponds and freshwater marshes (Fig. 5). In Sri Lanka, most of the threatened species, that are associated with aquatic habitats, are found in the central highlands with a very restricted distribution (Kottawa-Arachchi, 2017). 


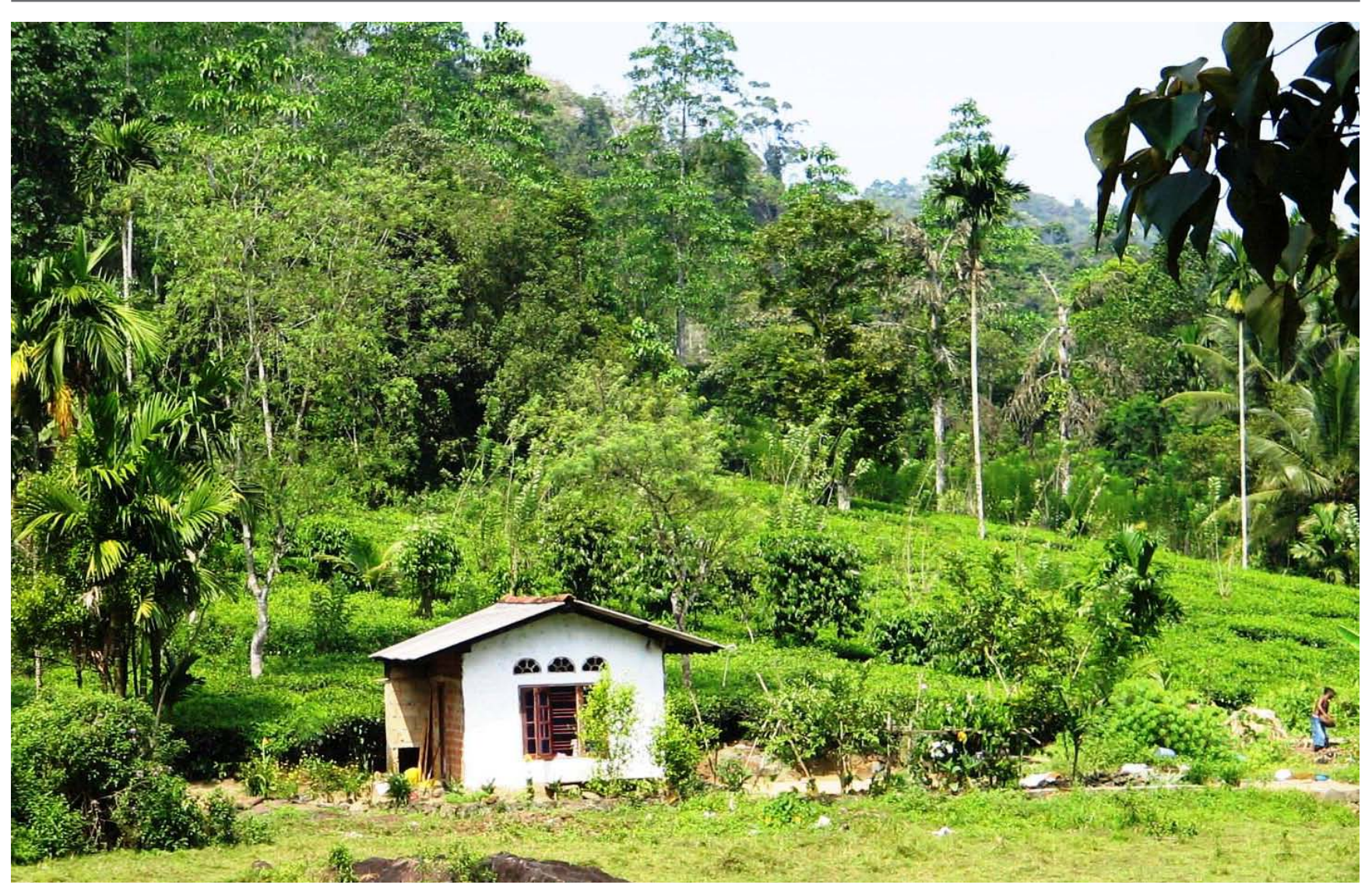

Fig. 4. Homegarden with tea (Camellia sinensis (L.) Kuntze) ecosystem.

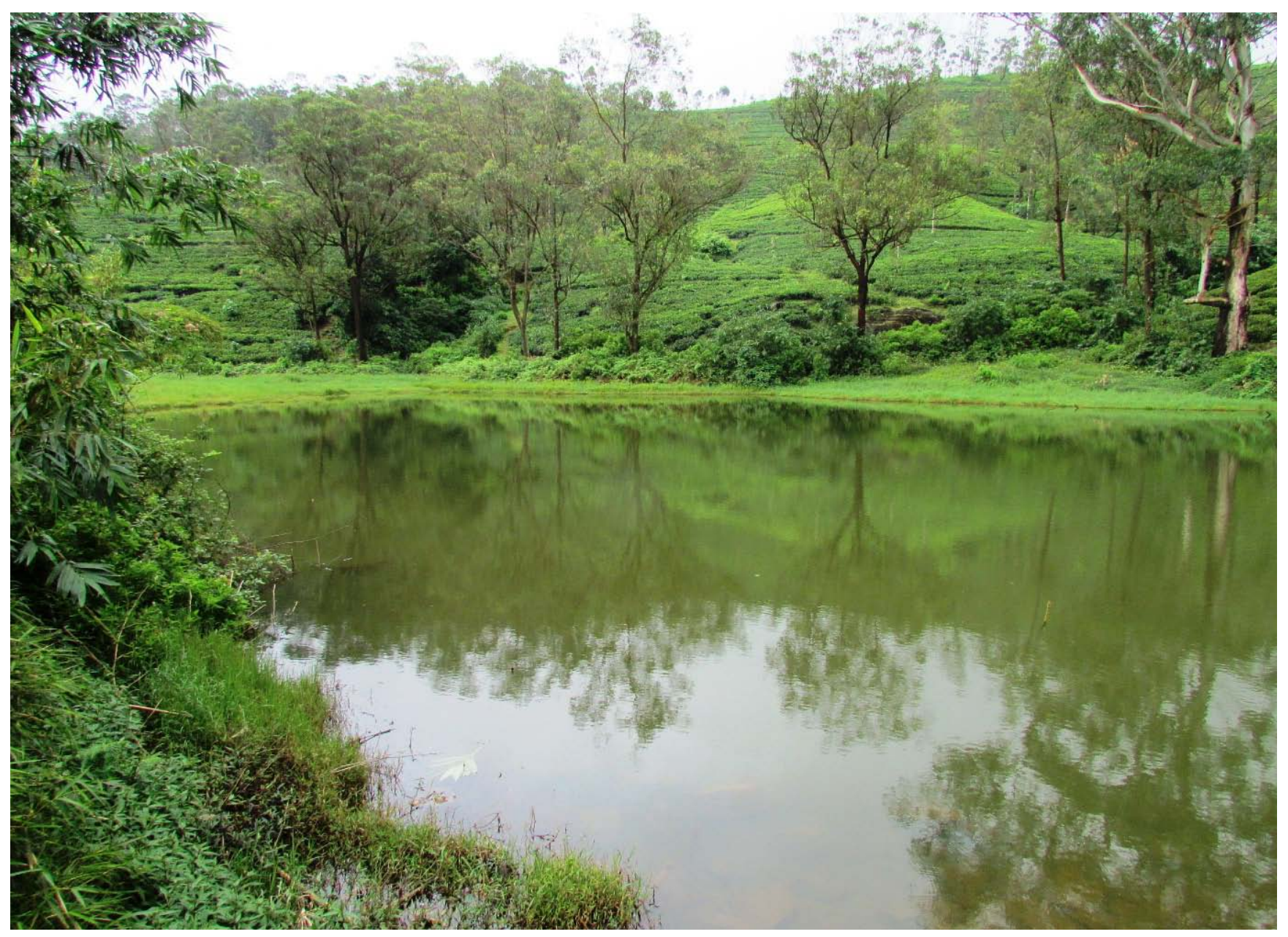

Fig. 5. Freshwater marsh in a tea plantation. 
Freshwater marshes that are associated with grasslands in Horton Plains National Park at higher elevations (above $1500 \mathrm{~m}$ above mean sea level) are subject to wide diurnal temperature fluctuations, especially during January to March, when rainfall is low and solar radiation is very high. During this period, the night temperatures near the ground surface drop below $0^{\circ} \mathrm{C}$ and midday temperatures go up to $28^{\circ} \mathrm{C}$ (Gunatilleke, 2007). On the other hand, marshlands in the tea plantation ecosystem at 1000-1500 m altitude in close proximity to natural forests exhibit distinct climatic fluctuations. However, night temperatures at ground level may drop to about $5-10^{\circ} \mathrm{C}$ during January to March. Besides, the night air temperatures in other wetland types such as streams and freshwater springs with a dense understory may go down only to about $16-19^{\circ} \mathrm{C}$ whereas the aquatic temperature in man-made lakes is about $17-22^{\circ} \mathrm{C}$ (Kottawa-Arachchi, 2017).

The species composition and the appearance of an aquatic ecosystem vary both temporally and spatially. Sri Lanka harbours over 370 aquatic macrophytes, of which $12 \%$ is endemic to the country (Yakandawala, 2012). Of the island's aquatic flora, $41 \%$ is now in the threatened category on the National Red List 2012 (MOE, 2012). This has to be considered seriously during the conservation of wetlands.

Sri Lanka has a variety of coastal and marine habitats that include large expanses of beaches, estuaries and lagoons, mangroves, salt marshes, sea grass beds, and several types of reefs, including coral reefs. The coastal ecosystems enable to perform many services as life supporting systems and to provide goods and services essential for humans and wildlife habitats. They include food fish, crustaceans and other fishery products, ornamental fish and salt. Further, coastal ecosystems in Sri Lanka have a great potential for the tourism industry (MOE, 2010). The coral reefs are still among Sri Lanka's most valuable shallow water marine ecosystems in terms of biodiversity and ecosystem services, though now considerably degraded due to coral bleaching (MOE, 2010).

\section{Impacts of climate change on biodiversity and ecosystems}

While the current and probable future impacts of climate change on agro-biodiversity are mostly uncovered, the possible impacts of climate change on wild biodiversity are still speculative. Nonetheless, the socio-economic and ecological implications of biodiversity loss in Sri Lanka will be considerable and wide ranging, because of probable changes in forests and other terrestrial systems, inland wetlands and coastal and marine systems and the species they contain (MOE, 2010).

Much of the climate research in Sri Lanka has been focused on the analysis of climatic variations over the past several decades, predicting the future climatic changes (de Costa, 2008; Jayawardene et al., 2015) and their impacts on agriculture and the adaptation strategies needed for a specific sector and for food security (Wijeratne et al., 2007a; Peiris et al., 2008; Esham \& Garforth, 2013). However, very little attention has been paid to the impact of climate change on species and ecosystems in Sri Lanka (Miththapala, 2015).

Over the past few decades climate change has been a much debated subject which attracted the attention of many biologists and ecologists. The drastic reduction of the forest cover has been identified as one of the major factors contributing to climate change. Based on the recent research findings, the annual rate of deforestation is $0.14 \%$ with 2.3 million $\mathrm{km}^{2}$ being lost between 2000 and 2012 worldwide (Khaine \& Woo, 2015). Deforestation directly contributes to climate change, leading to greenhouse gas (GHG) emissions and reducing the capacity of $\mathrm{CO}_{2}$ sequestration. It is established that deforestation and forest degradation jointly and significantly contribute to GHG emissions (IPCC, 2013).

\section{Flora}

Among lower plants, lichens, mosses, bryophytes, ferns and a few species of flowering plants occupy specific habitats such as open rocky areas and rocky seepage which are constantly washed-off by slowly escaping natural spring water. Also, the rocky seepage areas are safe places for several specially adapted small animals.

Bryophytes which comprise mosses (Bryopsida), liverworts (Marchantiopsida) and hornworts (Anthocerotopsida) have already long been recognised as very important components of almost all the earth's major ecosystems. Bryophytes are frequently found on damp and shady places, along riverbanks, edges of ponds and lakes, on tree trunks and even on man-made habitats. Further, bryophytes lack a proper cuticle or roots and therefore, they are highly sensitive to 
climate change, mainly temperature and rainfall variations. As a consequence of global warming, significant losses in bryophyte diversity can be expected, particularly in areas harbouring a large number of species, such as boreal forests of higher latitudes, alpine biomes and at higher altitudes of tropical mountains (He et al., 2016). Although many studies have been carried out on Sri Lankan flowering plants, the bryophyte flora of Sri Lanka remains poorly studied (Ruklani et al., 2015). Therefore, detail studies on distribution, ecology and the effect of rising temperatures and rainfall variations on Sri Lankan bryophyte flora are particularly important.

Among lower plant species, about 348 taxa of pteridophytes, from 30 families, have been recorded in Sri Lanka, including 50 endemic species. The majority of endemic pteridophytes (78\%) of Sri Lanka had been collected from the Central Province (Ranil \& Pushpakumara, 2012). Long duration of rainfall and a high relative humidity associated with the elevational gradient may be the reasons for the presence of a higher number of endemic taxa in the wet zone and the Central Province (Ranil \& Pushpakumara, 2012). This region is found to be highly subjected to habitat loss with the spread of alien-invasive species, soil erosion and environmental pollution. These problems will be worsened in future by the change of climate (Ranil \& Pushpakumara, 2012).

The study conducted during 25 years at Knuckles conservation area revealed that the decline of populations of several threatened plants such as Brachystelma lankana Dassan. \& Jayas., Dipcadi montanum (Dalzell) Baker and Didymocarpus humboldtianus Gardner have been adapted to seepage environment (Ekanayake, 2016). The study also suggested a strong possibility that the climate change has badly affected populations of those plants by way of making unfavourable moisture regimes, temperature extremes and the spread of bush fires during the dry season.

The dying back of tropical upper montane forests (Fig. 6) has become a severe environmental issue in Sri Lanka. The reasons for forest die back can be categorised into natural and anthropogenic factors. Among natural factors, climatic factors such as high radiation levels, heat, cold, drought and excess moisture are affecting forest dieback (Fernando, 2008). A high density of epiphytes, mosses, bryophytes and lichens are commonly found on trees in the montane forests. Several studies highlighted that about $38-90 \%$ of canopy trees have died due to forest die back in montane forests of Hakgala, Knuckles and Horton Plains National Park (Ranasinghe et al., 2009). Another study showed that tree species under the threatened category, Syzygium sclerophyllum Thwaites, Symplocos bractealis Thwaites, Calophyllum walkeri Wight, Cinnamomum ovalifolium Wight were highly susceptible to dieback (Adikaram \& Mahaliyanage, 1999). Besides, epiphytic populations, like many bryophytes, ferns and orchids, also drastically reduced with the dieback of trees. Among several hypothesis of dieback, drastic changes in the climatic condition such as severe drought or flood have been one of the causes for natural dieback in forests.

\section{Fauna}

Among 253 species of land snails, 179 species $(70 \%)$ have been listed in the threatened category including five endemic genera, namely Ravana, Ratnadvipia, Acavus, Oligospira and Aulopoma (MOE, 2012). The distribution is restricted to the lowland wet zone and some of them are considered as indicator species of the lowland rainforests. They require shade and constant moist conditions and are sensitive to high temperatures. Land snails are generally considered to be very sensitive to climate change. Recent observations suggested that a lack of living specimens of some of the above mentioned land snails was attributed to the recent dry weather conditions in certain areas of the lowland wet zone (Priyadarshana, 2016).

Since odonates rely almost entirely on water throughout their life, the changes in rainfall patterns and their water environment can adversely affect their existence significantly. Many of Sri Lanka's endemic odonates are found in the lowlands of the southwest and in the higher elevations and many are stream-dwellers in their larval stages (Poorten \& Conniff, 2012). Each species, however, is adapted to a particular type of stream: some require slowmoving or still water, others fast running water (Poorten \& Conniff, 2012). The researchers expect that the species well adapted to such specific environment might be mostly affected by the longer periods of drought which would reduce the stream flow and volume. Therefore, odonates are also used as an indicator for monitoring the effects of climate change on ecosystems. 


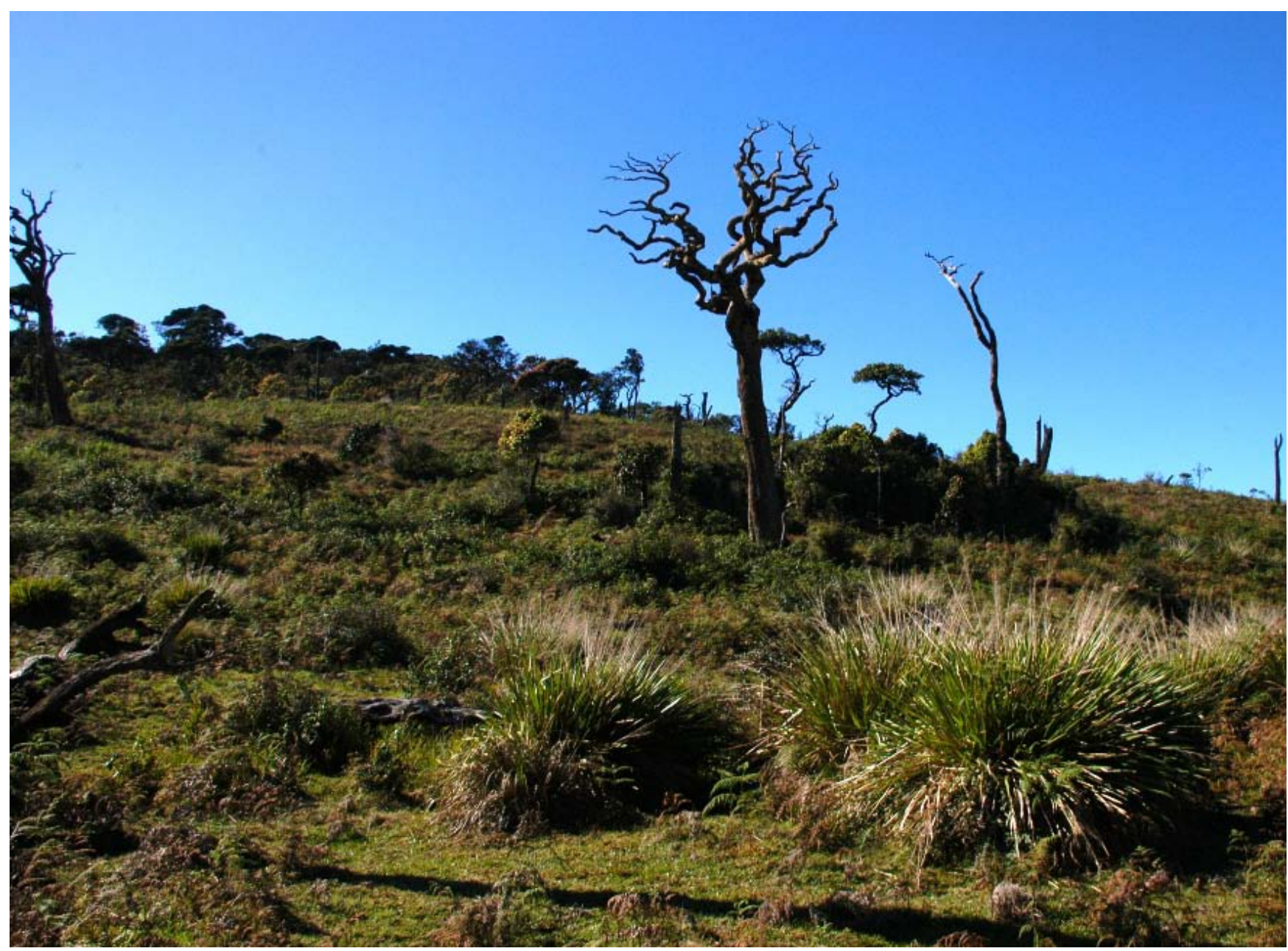

Fig. 6. Dying back of tropical upper montane forests.

Most of the invertebrate pollinators comprise bees, wasps, ants, beetles, butterflies, moths and flies. Some vertebrates such as bats and birds also contribute to the pollination (Punchihewa, 2013). Bees (Insecta: Hymenoptera) are the most important pollinators of flowering plants including agricultural crops, resulting in fruit and seed production. Communities of wasps and bees play a key role in ecosystem functioning and they have been used in studies of biodiversity assessment in different landuse types (Matos et al., 2013). The density and distribution of bees depend largely on climate, altitude and presence of suitable flowering plant species. A study conducted in Knuckles mountain range highlights the fact that the highest diversity of bees was at lower elevations where the climate was comparatively warmer (Karunaratne \& Edirisinghe, 2008). Therefore, the diversity of bees at different altitudes may provide clues to the likely responses of bee species and communities to climate change at any one point over time. Nevertheless, lower elevations with warmer environments are frequently affected by extreme climatic events such as high temperatures, droughts and floods as a result of climate change which could disrupt the population dynamics of bees.

Among the total number of butterfly species in Sri Lanka, 100 are recognised as threatened species (Poorten, 2012). The major factors that govern the distribution of butterfly species on the island are climate, topography and vegetation types. In general, a higher species richness of butterflies occurs in the foothill areas and several species are restricted to specific climatic zones, types of forests or grasslands (Poorten, 2012). The major threats to butterflies in Sri Lanka include destruction and degradation of habitats, air pollution, overuse of pesticides and natural factors such as prolonged droughts (MOERE, 2014), which are projected to be heightened due to climate change and an increase in the human population. Prolonged periods of drought experienced in different parts of the island during the 
past decade may have affected butterflies populations due to scarcity of food resources, and harsh environmental conditions (Perera \& Bambaradeniya, 2006). The disappearance of suitable habitats and larval food plants in all climatic zones is reflected in the reduced size of many populations of butterflies, particularly those that show seasonal mass movements (MOERE, 2014). This was evident with the drastic reduction of the population during the mass movements of Appias galene Felder \& Felder 1865, A. libythea Fabricius, 1775, Catopsilia pomona Fabricius, 1775, Hebomoia glaucippe Linnaeus, 1758 and Papilio crino Fabricius, 1793 when compared with what was seen a few decades ago (Poorten, 2012). The butterfly population found in highlands (cooler regions) may also be in danger due to the temperature rise with global warming and a lack of resources such as food and larval host plants that die off due to high temperatures and extreme weather conditions.

Sri Lanka supports a rich freshwater crab assemblage (Bahir \& Ng, 2005), which stands at 51 species within seven genera (Bahir \& Gabadage, 2012). Interestingly, 50 Sri Lankan freshwater-crab species and five of the genera (Ceylonthelphusa, Perbrinckia, Mahatha, Clinothelphusa and Pastilla) are endemic. According to the current conservation status of the freshwater crabs of Sri Lanka, nearly $90 \%$ of the freshwater crabs in Sri Lanka are globally threatened with $66 \%$ being listed under the category "critically endangered" (Bahir \& Gabadage, 2012). Nearly half of the freshwater crabs known to-date (23 species) are point endemics, rendering them extremely vulnerable to habitat loss, degradation and stochastic events (Bahir \& Gabadage, 2012). Further, prolong drought, rainwater acidification, soil erosion leading to sedimentation of water bodies and landslides due to intensive rain can be considered as major threats on the habitats of the freshwater crabs in Sri Lanka (Bahir \& Gabadage, 2012).

Sri Lanka also owns a rich freshwater fish assemblage, comprising 91 species, including 50 endemics (Pethiyagoda et al., 2012a). Arguably, the freshwater fish are the most vulnerable taxonomic group to climate change as most of the threatened or endemic freshwater species are found in streams that are lying outside the Protected Area Network of Sri Lanka. Several (critically) endangered species, such as Pethia bandula (Kottelat \& Pethiyagoda, 1991), Stiphodon martenstyni Watson, 1998, Rasboroides nigromaginata (Meinken, 1957), Dawkinsia srilankensis (Senanayake, 1985), Laubuca insularis (Pethiyagoda, Kottelat, Silva, Maduwage \& Meegaskumbura, 2008), Systomus martenstyni (Kottelat \& Pethiyagoda, 1991), Labeo fisheri (Jordan \& Starks, 1917), and Labeo lankae (Deraniyagala, 1952), are only found at a single location (point endemics) or in a single river basin (Goonatilake, 2012). Habitat destruction due to anthropogenic activities is the major threat to those species while climate change impacts, including extended drought and sedimentation of water bodies due to landslides, may trigger the declining of populations.

The knowledge on Sri Lanka's amphibians has increased rapidly during the past decade. To date, valid descriptions of 111 amphibian species have been published (Manamendra-Arachchi \& Pethiyagoda, 2005; Meegaskumbura et al., 2010). This includes 95 endemic species and three endemic genera, Adenomus, Lankanectes and Nannophrys. In Sri Lanka, the majority of the endemic and threatened amphibians are confined to the wet zone and especially to the montane ecosystem (Rajakaruna et al., 2007; Erdelen, 2012). Recent studies conducted in the montane ecosystem, including natural forest and tea plantations, revealed that several endangered amphibians, like Taruga eques (Günther, 1858) and Pseudophilautus sarasinorum (Müller, 1887), are restricted to specific aquatic habitats such as seasonal streams and marshy lands (Kottawa-Arachchi \& Gamage, 2015a; Kottawa-Arachchi et al., 2015b). Another endemic amphibian genus, Nannophrys, with four species (including one extinct species $N$. guentheri (Boulenger, 1882)), is highly specific to rocky cascades, wet rock surfaces and under boulders where conditions are moist. Especially the endangered species $N$. marmorata (Kirtisinghe, 1946) and N. naeyakai (Fernando, Wickramasingha \& Rodrigo, 2007) are restricted to Knuckles and Kokagalla hills (Fernando et al., 2007). The vegetation and the water sources of the habitats are rapidly dried out by desiccating south-west monsoon winds in July - October. 
Most of the described extant species of the Sri Lankan genus Pseuophilautus (oriental tree shrub frogs) occur in the south-western wet zone; the distribution of these species is probably determined by the dependence on loose, moist, shaded soil in which their eggs are deposited (Bahir et al., 2005). The critical humidity dependence of Philautus eggs makes them vulnerable to even short periods of desiccation. Global warming could therefore place this fauna at risk, although arboreal nesters appear to be more immediately threatened than ground nesters (Bahir et al., 2005; Miththapala, 2015).

Besides, desiccation of habitats, due to droughts and other climatic changes such as an increase in atmospheric temperature, may also cause biological changes in the species, resulting in a population decline (Wickremasinghe, 2016). In 1992, mass deaths of the endangered pigmy lizard (Cophotis ceylanica (Peters, 1861)) were observed around Hakgala (1500 m above mean sea level) and Nuwara Eliya (1800 m above mean sea level) within a few days. An extended drought with high temperatures reported during this period is believed to have been the major contributory factor (de Silva, 2006).

\section{Ecosystems}

Ecosystems vulnerable to the changes in climate in Sri Lanka are the intensively cultivated agricultural lands, plantation croplands at high altitudes, montane forests and grasslands (Iqbal et al., 2014). A continuous flow of food production, coastal and marine resources, tourism and recreation etc. can be identified as some of the ecosystem services. Due to prolonged droughts and flash floods brought about by extreme rainfall events with the changes of monsoon pattern, sea level rise and increasing temperatures affect essentially the above mentioned ecosystem services (Jayathunga \& Gunarathne, 2016). Often Sri Lanka experiences very hot weather, with certain regions reaching record temperatures and a very high intensity of precipitation. Although Sri Lanka is a small country, droughts and floods occur simultaneously in different parts of the country showing the variation of extreme weather conditions.

Agriculture is particularly prone to weather-related risks such as droughts, floods and extreme temperatures. Being exposed to such climatic extremes, agriculture is an extremely vulnerable ecosystem in Sri Lanka which has a potentially serious consequence for food production and food security (Weerakoon, 2013). Increase in temperature reduces fertility which decreases self-pollination of many major food crops. With the existing Sri Lankan rice varieties, increase in temperature by about $2{ }^{\circ} \mathrm{C}$ would decrease their productivity by over $20 \%$ (Weerakoon, 2013).

A rising temperature followed by prolong droughts is a major constraint to the sustainability and productivity of major Sri Lankan plantation crops such as tea, coconut and rubber (Wijeratne et al., 2007a). The pollen germination ability, production of female flowers and fruit set of coconut, reduce due to heat and drought stress (Ranasinghe, 2013). Tea is grown primarily as a rain fed plantation crop and the tea yield is greatly influenced by the weather. With prolong drought, a considerable loss of crop production and increased casualties of tea have been observed in various tea growing regions in Sri Lanka (Nawaratne, 1992, Yatawatte, 1992, Damayanthi et al., 2010).

It is in the montane zone that climate change impacts are already being felt: the annual mean minimum air temperatures at night time have increased maximally in the Nuwara Eliya District (Basnayake, 2007). In addition, the highest rate of decline in rainfall has also been shown to be in Nuwara Eliya (de Costa, 2008). Increasing trends of diurnal temperatures may extend the temperature boundaries for invasive alien plants (Iqbal et al., 2014). The occurrence of extended drought periods in the dry zone of Sri Lanka can increase the mortality of the native flora followed by replacement with invasive species. The occurrence of floods can create ecosystem disturbances in conserved areas while facilitating the dispersal of seeds of invaders (Iqbal et al., 2014).

A projected sea level rise (IPCC, 2013), due to the climate change, poses threat to the coastal ecosystems, especially the mangroves (Fig. 7), bays etc. around the island. Rising water levels in mangroves and intrusion of saline water to inland water bodies can harm the habitats of plants and animals well adapted to the present ecological conditions. 


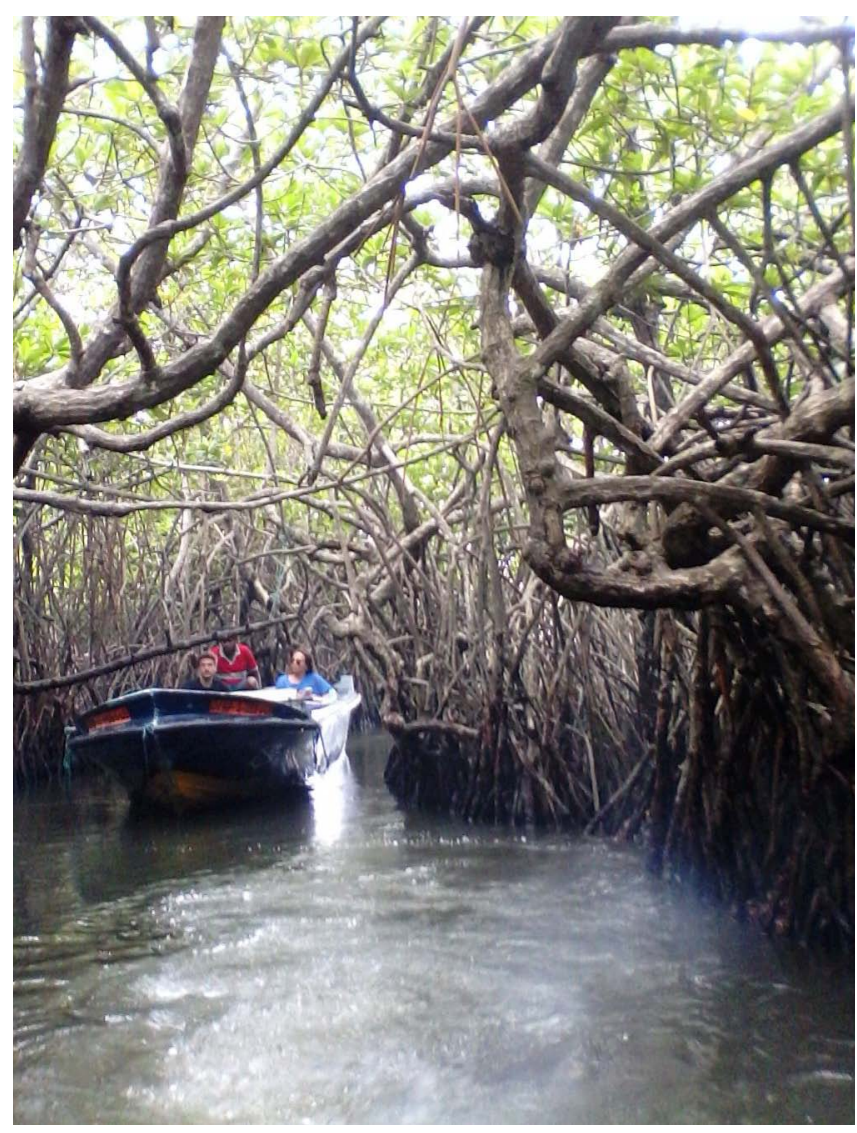

Fig. 7. Mangrove ecosystem.

\section{Biodiversity responses to climate change}

High temperatures and changes of rainfall pattern may provide conductive environmental conditions for a rapid growth of some plant species including invasive species which would suppress the growth of others, thus disturbing the ecological balance. This would result in a lack of food for various insects and animals endangering their existence and distribution. Some hardto-kill-weeds that are well adapted to adverse climatic conditions such as dry weather and poor soil conditions can grow profusely under climate change reducing land productivity and forcing farmers to use more agrochemicals to sustain crop growth and yield. However, a heavy use of agro-chemicals can adversely affect the presence of predators of pests and biodiversity in such lands and surroundings. Further, a change of the wind pattern and humidity in different ecological regions as a result of the climate change may pose threat to the distribution of flora and fauna.

A shift in distinct vegetation types, referred to as biome or habitat shift, is often simulated with Dynamic Vegetation Models (Bellard et al., 2012). Several studies revealed that selected plant communities show an upward and poleward shift, but with some inconsistencies (Fei et al.,
2017). The upward shifts of trees, primarily in response to a temperature change, have been observed in a wide range of studies (Lenoir et al., 2008; Feeley et al., 2011). Poleward shifts of tree species have also been observed worldwide.

Shifts of terrestrial flora are obviously visible and their changes more easily observed than of aquatic species. In Sri Lanka several plant species such as Artocarpus heterophyllus Lam. (Jak) and Mangifera indica L. (Mango), which are generally confined to low elevations (less than $1000 \mathrm{~m}$ above mean sea level) (Ashton et al., 1997) have been established and successfully reproduced at higher elevation (up to $1400 \mathrm{~m}$ ), in the Nuwara Eliya District (Kottawa-Arachchi et al., 2015b). This can be a result of rising temperatures by which change the climatic conditions at high elevation may have reached the required range for growing such fruit crops. De Costa (2008) has shown that the Nuwara Eliya District recorded the highest rate of warming (greater than the global average

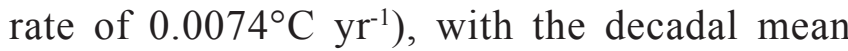
temperature showing an almost continuous increase for the period between 1906 and 2005.

The tree and forest growth rate is significantly correlated with climate. The growth rate is strongly influenced by water availability (Toledo et al., 2011). The growth rate of trees in the tropical region increases with sufficient water availability and increasing temperatures (Toledo et al., 2011). However, the growth will reduce with prolong droughts. Usually, the growth rate of trees shows a positive response to increasing temperature and precipitation of the tropical region (Wagner et al., 2014).

Increase in temperature and reduction in rainfall due to global warming can adversely affect the productivity and sustainability of plantation crops in Sri Lanka, such as tea, in the future. This is true for many other tea growing countries in the region, too (Bhagat et al., 2016). The abandonment of a large extent of such plantations in hilly areas due to low productivity as a result of any adverse impacts of climate change can bring dire consequences such as soil erosion and loss of biodiversity. A detailed study showed that tea cultivations at low and mid elevations are more vulnerable to adverse impacts of climate change (Fig. 8) than those at high elevations in Sri Lanka (Wijeratne et al., 2007a). 


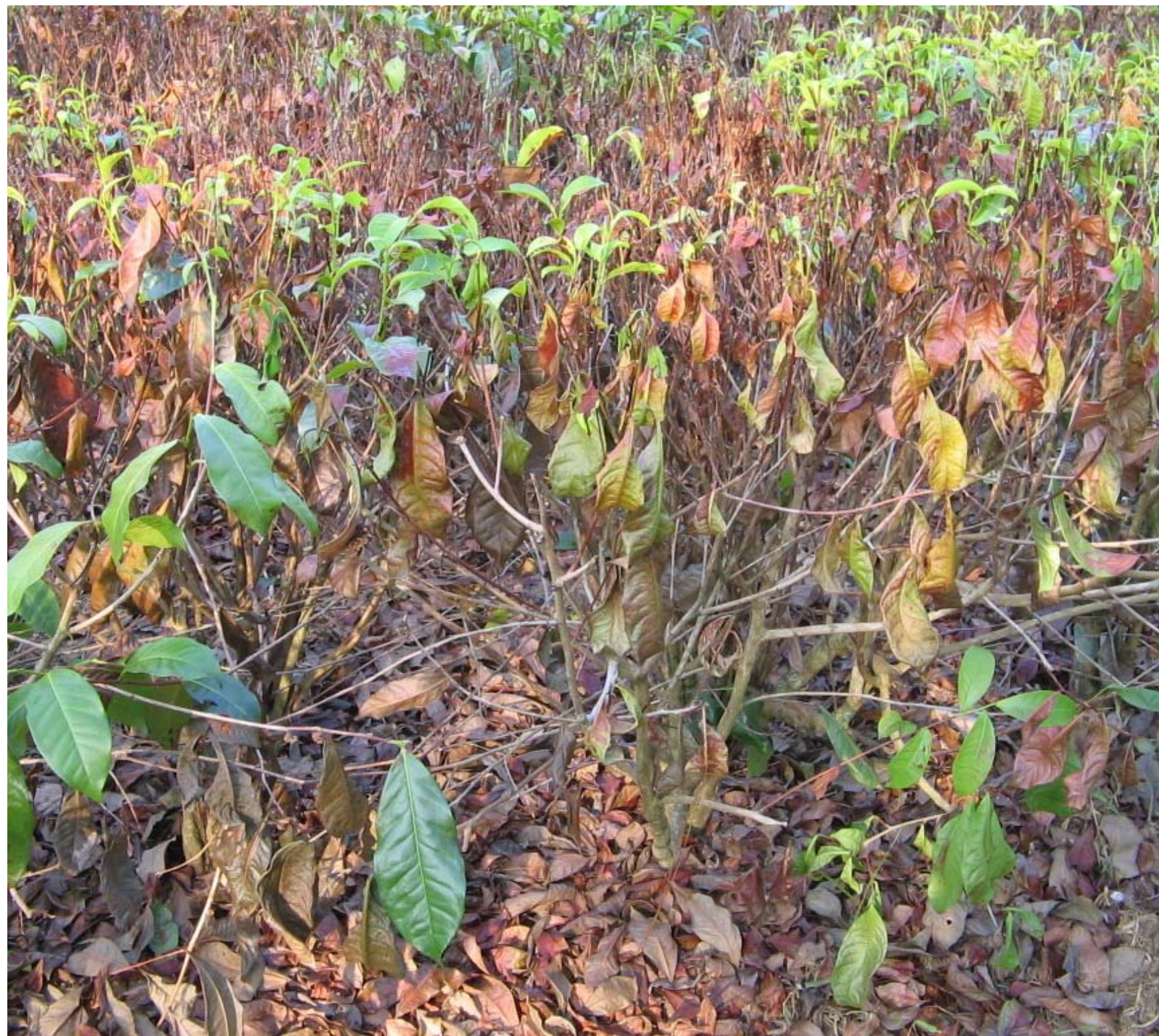

Fig. 8. Drought affected tea bushes at low elevation.

\section{Loss of species}

The climate change poses a serious threat to species persistence. An effective modelling of evolutionary responses to the rapid climate change is therefore essential. Many of the Earth's species are already at risk of extinction due to pressure from natural processes or human activities. The climate change will add to this pressure, while for a few species the pressure could be alleviated by the climate change (Dawson et al., 2011; Fei et al., 2017). There are three main approaches to projecting species loss viz., concentrating either on future changes in species range or species extinction or changes in species abundance (Bellard et al. 2012).

Pollinators are a key component of the global biodiversity, providing vital ecosystem services to crops and wild plants (Potts et al., 2010). Climatic changes have adversely affected the distributions of butterflies and bees in Sri Lanka (Karunaratne \& Edirisinghe, 2008; Matos et al., 2013; MOERE, 2014). Several studies found the relationship between the climate change and a decline of the bee population in Europe (Williams et al., 2007; Dormann et al., 2008). The climate change appears to be contributing to mismatch between pollinators and plants. The flowering time of plants is likely to be changed in response to regional climatic variations. As a result, the synchrony of plants and pollinators may be changed. Punchihewa (2013) has shown that the abundance and distribution of plants and pollinators in response to the climate change is presently 
taking place in Sri Lanka. Rising temperatures and extreme weather conditions, especially high rainfall variability, droughts and extreme wet weather conditions accompanied by overcast conditions (lack of sunlight), may disrupt flowering patterns of plants. Additionally, forest fires, deforestation, encroachments, village expansion, infrastructure development, allotment of lands etc. in Sri Lanka also reduce the population of flowering plants, reducing the food and habitats for pollinators. In addition to the impacts of climate change, a lack of knowledge on ecosystems services also contributes to such environmental damages.

The Global Amphibian Assessment, conducted in 2004, has shown that out of the 34 species of amphibians confirmed as extinct worldwide in the last 500 years, 21 are from Sri Lanka. Many species of amphibians are at a high risk of becoming extinct and habitat loss is the main threat. They comprise 19 species belonging to the genus Pseudophilautus, and one species each of the endemic genera Adenomus and Nannophrys. The vast majority of the amphibians are restricted to the south-western wet zone (Dutta \& Manamendra-Arachchi, 1996), which is highly vulnerable to climate change.

Therefore, it is imperative that monitoring be carried out, at least in major bio-geo-climatic zones and prominent habitats within these zones. In addition to monitoring populations, it is also necessary to acquire data on parameters known to pose threats to amphibians, such as UV radiation, water quality and climatic variations (ManamendraArachchi \& Meegaskumbura, 2012). Therefore, climate change impacts on amphibians and their specific habitats need to be addressed for future management and conservation.

\section{Projections for future climate}

As per global projections (IPCC, 2013), the mean ambient temperature rise for the period between 2046 and 2065 will be in the range of $1-2^{\circ} \mathrm{C}$ and that for $2081-2100$ period will be nearly $1-3.7^{\circ} \mathrm{C}$. The temperature rise in the Asian region projected for the latter period can be as high as $2-3^{\circ} \mathrm{C}$. Further, rainfall is projected to increase by about $10-20 \%$ during 2081-2100 and the intensity and period of dry weather will likely to be increased at the end of the century.

Global projections show that the summer monsoon in the tropical region will significantly increase (IPCC, 2013). Warm days and warm nights are also expected due to the climate change. It is the experience of the local climatologist in Sri Lanka that the increase of rainfall could be largely attributed to an increase in rainfall intensity during rainy peak seasons. This will lead to the occurrence of extreme weather events where wet periods become wetter and dry periods become dryer in years to come. The increasing rainfall variability, especially in South Asia is also a result of the climate change. Heavy rainfall events can cause soil erosion, landslides (Fig. 9), floods (Fig. 10) and excess moisture stagnation in low lying areas. In contrast, extended droughts reduce the growth of vegetation and availability of water for living organisms. With the continuing anthropogenic activities, the $\mathrm{CO}_{2}$ levels are increasing more and more. It has been reported that the $\mathrm{CO}_{2}$ had increased at a rate of 1.9-2.01 ppm/yr during 2002-2011 (IPCC, 2013).

The sea level rise is also reported to be a consequence of global warming. Sri Lanka, being a small island country, is predicted to be vulnerable to such a sea level rise. The global sea level rise during the last century has been in the range of $0.17-0.21 \mathrm{~m}$ with an average of 0.19 $m$ (IPCC, 2013). As per the global projections based on different scenarios, the global mean sea level rise by the year 2046-2065 would be $0.24-0.30 \mathrm{~m}$ and that for 2081-2100 would be around $0.26-0.82 \mathrm{~m}$ (IPCC, 2013). The coastal regions are also expected to be affected by sea level extremes and high waves. Salt water intrusion and high waves can adversely affect biodiversity in the coastal ecosystems. Being an island country with long beaches, such impacts are very significant for Sri Lanka.

\section{Limitation of monitoring of climate change impacts}

Climate change impacts are felt by all facets and sectors, covering flora, fauna and environment. However, greater attention has presently been paid to the analysis of climate change and its impacts on agriculture and human health. It is obvious that the sustenance of life on earth is largely dependent on the biodiversity. Being an island country rich in biodiversity, monitoring of climate change impacts on biodiversity is of paramount importance, especially for minimising the adverse impacts and protecting the 
biodiversity in Sri Lanka. Further, the agriculture sector covering a large proportion of lands in all climatic regions and terrains from the coastal belt to the mountainous regions immensely contribute to biodiversity in Sri Lanka. For instance, the plantation sector (tea, rubber \& coconut, etc.) covers over $8000 \mathrm{~km}^{2}$, which provides a habitat for a large part of the flora and fauna in Sri Lanka (MOE, 2010). Although the impacts on crop yields have been investigated, that on biodiversity in the agriculture sector have not been fully understood yet. Due to pressure from the ever rising population and expansion of industries etc., the demand for land has been tremendously increased. Often, agricultural lands are used for such purposes, impacting biodiversity. However, information and precise data on the impacts of such land use changes on biodiversity is lacking. Being a developing country with many economic challenges, the funds and expertise available for monitoring climate change impacts and biodiversity conservation are not sufficient either. A large variation in climatic conditions and land terrains on the island is a challenge for the limited number of scientists and conservators.

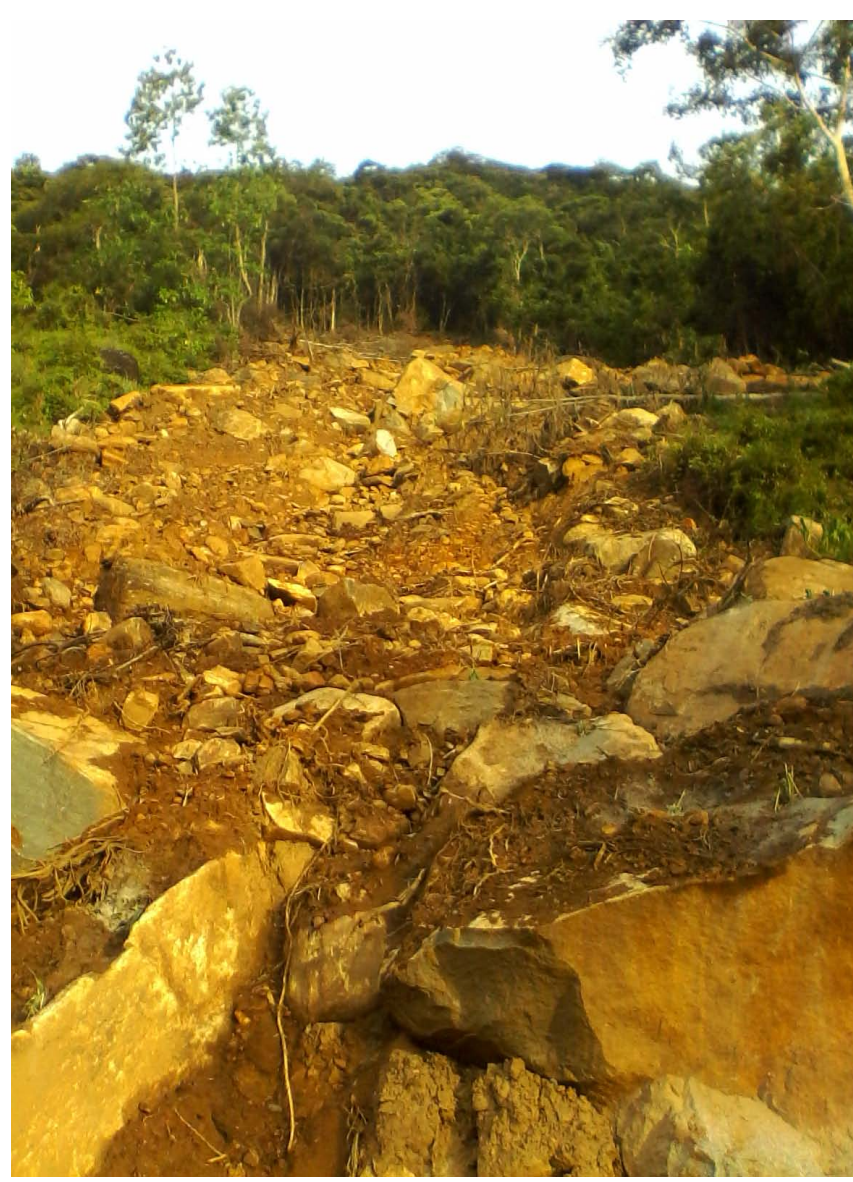

Fig. 9. Landslide due to heavy rainfall.

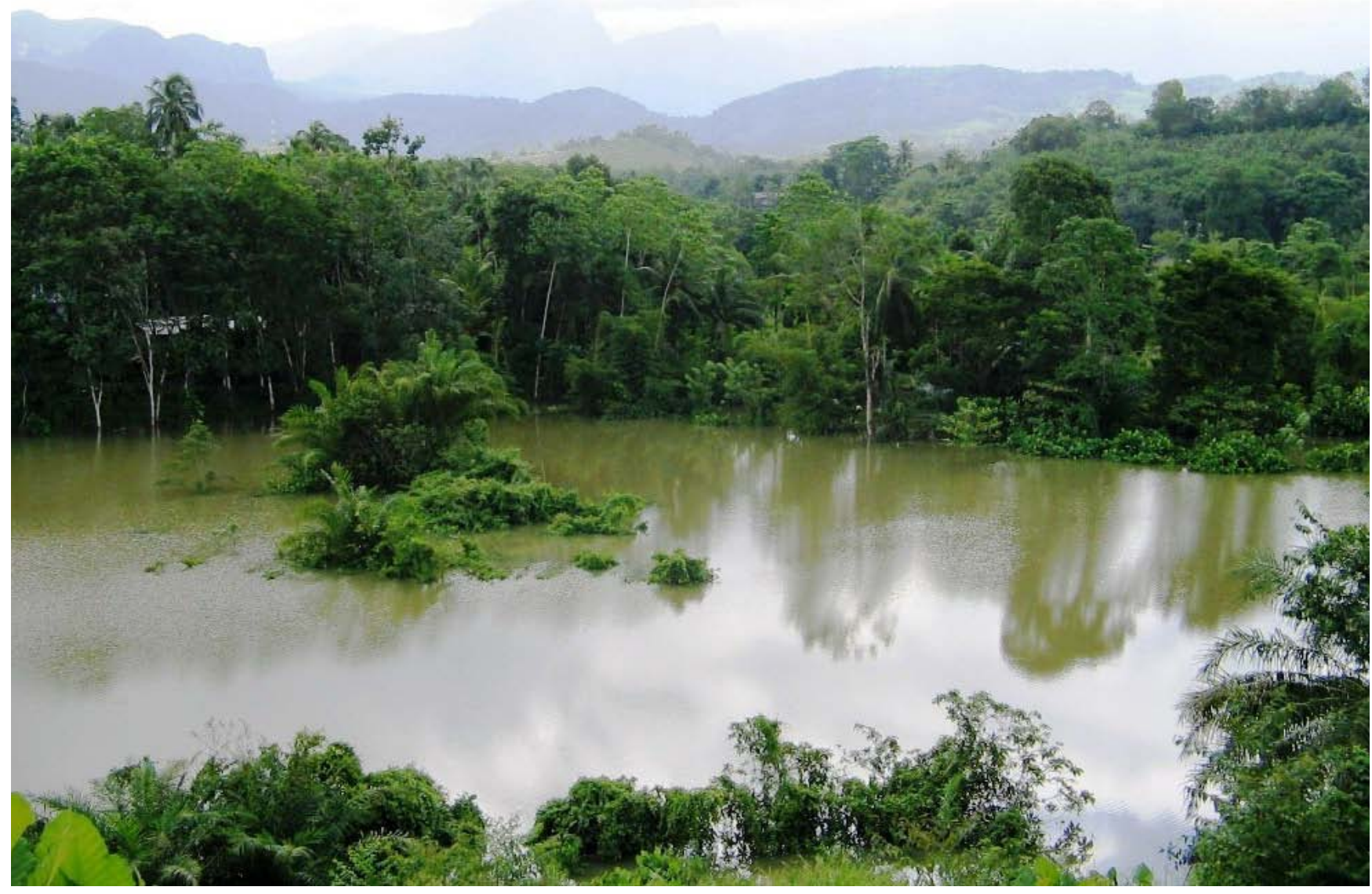

Fig. 10. Flood in lowlands. 
In Sri Lanka there are 46 agro-ecological regions classified, based on rainfall, elevation, soil and landform. However, meteorological stations are not available for recording data representing all the agro-ecological regions with distinct variation in biodiversity, which is also a limiting factor. Due to the grave importance, the conservation of ecosystems and biodiversity is often in the forefront of the political agendas as well. Although there are government acts, policies and guidelines to safeguard soil, environment, biodiversity and other natural resources, they have not been very effective on ground due to a lack of investment and awareness among the general public and users of such natural resources. Hence, it is essential that this field of science is provided with substantial and broad-based financial support to carry out climate change research including that of fundamental nature (de Costa, 2012). It is also pertinent to note that there is no co-ordinated national strategy to combat the impending adverse impacts of climate change on different sectors of the national economy, on different geographical zones of the country and on different strata of its population (de Costa, 2012). Further, dismantling of responsibilities on ecosystems biodiversity conservation among various organisations has also been a negative factor in this regard.

\section{Adaptation of climate change impacts and future directions}

The introduction of various policies and guidelines in relation to environment is a good sign for conservation of ecosystems and biodiversity. A number of government organisations and non-government organisations are engaged in some monitoring and conservation of ecosystems and biodiversity in Sri Lanka. Many entrepreneurs are now promoting environmentally sound technologies, energy and timber plantations and ecotourism. Such initiatives help improving and preserving the biodiversity. Being a small island country, coastal conservation becomes very important, not only because of shrinking land extent and threat to public property, but also to protect specific ecosystems and biodiversity inherited by those locations. Having separate governmentled institutions for coastal conservation in Sri Lanka is considered a strength in biodiversity conservation. As many people are dependent on forest reserves, coastal resources, inland water resources for their livelihood, it is important to get the community involved in ecosystem and biodiversity conservation. Further, entrepreneurs who are already contributing to conserve ecosystems and biodiversity are now showing interest in claiming for ecosystem services.

According to the recent studies, warming would also result in plant and animal species in the lowlands gradually migrating upwards, putting existing montane populations of plants and animals under increasing stress (Pethiyagoda, 2012b). A lack of knowledge on shifting patterns of plant communities in Sri Lanka warrants in-depth and long term studies focusing on the population dynamics or upward shifting of Sri Lankan plant communities. It is also important to highlight that much of the montane forest surroundings have been replaced by monoculture forest plantations such as Eucalyptus, Pinus and plantation crops such as tea. Therefore, it is essential to investigate the possible impacts of climate change on productivity of plantation crops covering large extents especially in biodiversity sensitive areas and propose suitable adaptation measures to arrest any adverse impacts (Wijeratne, 1996; Bhagat et al., 2016).

Homegardens are complex sustainable land used systems that combine multiple farming components such as annual and perennial crops which provide household needs, income generation opportunities and many environmental services (Marambe et al., 2013). Although, the composition of homegardens in Sri Lanka has not changed substantially (Pushpakumara et al., 2012), it is important to pay special attention on the changes made to the composition of homegardens under a variable and changing climate aiming at future food and nutrition security of the household (Marambe et al., 2013).

Further, appreciable progress has been achieved in implementing environmentally sound projects with government commitment such as UNREDD+ aiming at reducing deforestation and degradation of natural forests in Sri Lanka. Sri Lanka submitted a Nationally-Determined Contribution (NDC) to the United Nation Framework Convention on Climate Change (UNFCCC) in September 2016, which was a revised description of its Intended Nationally- 
Determined Contribution submitted in the runup to Paris, which includes a target to increase the national forest cover from $29.7 \%$ to $32 \%$ by 2030 (MOMDE, 2017).

Policies and measures already developed under such initiatives will no doubt preserve natural habitats for plant and animal species. The organic farming and strict regulation and directions for minimum pesticide use in agricultural lands also positively contribute to biodiversity conservation in Sri Lanka. The pressure from nature lovers for conservation of environment in mega development projects is also a good sign in biodiversity conservation.

\section{References}

Adikaram N.K.B., Mahaliyanage T.D. 1999. Study of phytosociology and forest health: Final report, Horton Plains forest dieback research project. Peradeniya: University of Peradeniya. P. 22-122.

Aratrakorn S., Thunhikorn S., Donald P.F. 2006. Changes in bird communities following conversion of lowland forest to oil palm and rubber plantations in southern Thailand. Bird Conservation International 16(1): 7182. DOI: $10.1017 / \mathrm{S} 0959270906000062$

Ashton M., Gunatilleke S., de Zoysa N., Dassanayake M.D., Gunatilleke N., Wijesundara S. 1997. A field guide to the common trees and shrubs of Sri Lanka. Colombo: Wildlife Heritage Trust. $432 \mathrm{p}$.

Bahir M.M., Meegaskumbura M., Manamendra-Arachchi K., Schneider C.J., Pethiyagoda R. 2005. Reproduction and terrestrial direct development in Sri Lankan shrub frogs (Ranidae: Rhacophorinae: Philautus). Raffles Bulletin of Zoology Suppl. 12: 339-350.

Bahir M.M., Ng P.K.L. 2005. Description of ten new species of freshwater crabs (Parathelphusidae: Ceylonthelphusa, Mahatha, Perbrinckia) from Sri Lanka. Contributions to Biodiversity Exploration and Research in Sri Lanka. The Raffles Bulletin of Zoology Suppl. 12: 47-75.

Bahir M.M., Gabadage D.E. 2012. Taxonomy and conservation status of freshwater crabs (Crustacea: Decapoda) in Sri Lanka. In D.K. Weerakoon, S. Wijesundara (Eds): The National Red List 2012 of Sri Lanka; Conservation status of the fauna and flora. Colombo, Sri Lanka: Ministry of Environment. P. 58-64.

Basnayake B.R.S.B. 2007. Climate change. In: The National Atlas of Sri Lanka. Colombo, Sri Lanka: Government Press. P. 54-55

Bellard C., Bertelsmeier C., Leadley P., Thuiller W., Courchamp F. 2012. Impacts of climate change on the future of biodiversity. Ecology Letters 15: 365-377. DOI: $10.1111 / \mathrm{j} .1461-0248.2011 .01736 . x$

Bhagat R.M., Ahmed K.Z., Gupta N., Baruah R.D., Wijeratne M.A., Bore J.K., Nyabundi D.W., Han W., Li X., Yan P.,
Ahammed G.J. 2016. Report of the working group on climate change of the FAO intergovernmental group on tea. Rome: Food and Agriculture Organization of the United Nations. 84 p.

Botkin D.B., Saxe H., Araujo M.B., Betts R., Bradshaw R.H.W., Cedhagen T., Chesson P., Dawson T.P., Etterson J.R., Faith D.P., Ferrier S., Guisan A., Hansen A.S., Hilbert D.W., Loehle C., Margules C., New M., Sobel M.J., Stockwell D.R.B. 2007. Forecasting the effects of global warming on biodiversity. BioScience 57(3): 227-236. DOI: 10.1641/B570306

de Costa W.A.J.M. 2008. Climate change in Sri Lanka: myth or reality? Evidence from long-term meteorological data. Journal of the National Science Foundation of Sri Lanka 36(Special Issue): 63-88.

de Costa W.A.J.M. 2012. Climate change research in Sri Lanka - Are we investing enough? Journal of the National Science Foundation of Sri Lanka 40(4): 281-282. DOI: $10.4038 /$ jnsfsr.v40i4.5041

de Silva A. 2006. Current status of the reptiles of Sri Lanka. In: C.N.B. Bambaradeniya (Ed.): Fauna of Sri Lanka: Status of taxonomy, research and conservation. Colombo, Sri Lanka: The World Conservation Union \& Government of Sri Lanka. P. 134-163.

Damayanthi M.M.N., Mohotti A.J., Nissanka S.P. 2010. Comparison of tolerant ability of mature field grown tea (Camellia sinensis L.) cultivars exposed to a drought stress in Passara area. Tropical Agricultural Research 22(1): 66-75. DOI: 10.4038/ tar.v22i1.2671

Dawson, T.P. Jackson S.T., House J.I., Prentice I.C., Mace G.M. 2011. Beyond predictions: biodiversity conservation in a changing climate. Science 332: 53 58. DOI: $10.1126 /$ science. 1200303

Dela J.D.S. 2009. Fourth country report from Sri Lanka to the United Nations convention on biological diversity. Battaramulla, Sri Lanka: MoE. 150 p.

Dormann C.F., Schweiger O., Arens P., Augenstein I., Aviron St., Bailey D., Baudry J., Billeter R., Bugter R., Bukacek R., Burel F., Cerny M., de Cock R., de Blust G., de Filippi R., Diekotter T., Dirksen J., Durka W., Edwards P.J., Frenzel M., Hamersky R., Hendrickx F., Herzog F., Klotz St., Koolstra B., Lausch A., Coeur D.L., Liira J., Maelfait J.P., Opdam P., Roubalova M., Schermann-Legionnet A., Schermann N., Schmidt T., Smulders M.J.M., Speelmans M., Simova P., Verboom J., Wingerden W.V., Zobel M. 2008. Prediction uncertainty of environmental change effects on temperate European biodiversity. Ecology Letters 11: 235-244. DOI: 10.1111/j.1461-0248.2007.01142.x

Dutta S.K., Manamendra-Arachchi K. 1996. The amphibian fauna of Sri Lanka. Colombo: Wildlife Heritage Trust of Sri Lanka. 230 p.

Easterling D.R., Meehl G.A., Parmesan C., Changnon S.A., Karl T.R., Mearns L.O. 2000. Climate extremes: 
observations, modeling, and impacts. Science 289(5487): 2068-2074. DOI: 10.1126/science.289.5487.2068

Edirisinghe E.A.P.N., Ariyadasa K.P., Chandani R.P.D.S., 2012. Forest cover assessment in Sri Lanka. The Sri Lanka Forester 34: 1-12.

Ekanayake S.P. 2016. Declining populations of some threatened plants associated with rocky seepages in Knuckles area. NeelaHaritha: The Climate Change Magazine of Sri Lanka Inaugural volume: 125-126.

Erdelen W.R. 2012. Conservation of biodiversity in a hotspot: Sri Lanka's amphibians and reptiles. Amphibian and Reptile Conservation 5: 33-51.

Esham M., Garforth C. 2013. Climate change and agricultural adaptation in Sri Lanka: a review. Climate and Development 5(1): 66-76. DOI: 10.1080/17565529.2012.762333

Feeley K.J., Silman M.R., Bush M.B., Farfan W., Cabrera K.G., Malhi Y., Meir P., Revilla N.S., Quisiyupanqui M.N.R., Saatchi S. 2011. Upslope migration of Andean trees. Journal of Biogeography 38(4): 783-791. DOI: 10.1111/j.1365-2699.2010.02444.x

Fei S., Desprez J.M., Potter K.M., Jo I., Knott J.A., Oswalt C.M. 2017. Divergence of species responses to climate change. Science 3(5): e160305. DOI: 10.1126/ sciadv. 1603055

Fernando G.W.A.R. 2008. Causes of forest dieback in montane forests in Sri Lanka. Economic Review 34: 38-40.

Fernando S.S., Wickramasingha L.J.M., Rodirigo R.K. 2007. A new species of endemic frog belonging to genus Nannophrys Gunther, 1869 (Anura: Dicroglossinae) from Sri Lanka. Zootaxa 68(1403): 55-68.

Ficetola G.F., de Bernardi F. 2004. Amphibians in a humandominated landscape: the community structure is related to habitat features and isolation. Biological Conservation 119: 219-230. DOI: 10.1016/j.biocon.2003.11.004

Gallmetzer N., Schulze C.H. 2015. Impact of oil palm agriculture on understory amphibians and reptiles: A Mesoamerican perspective. Global Ecology and Conservation 4: 95-109. DOI: 10.1016/j. gecco.2015.05.008

Goonatilake S.A. 2012. The Taxonomy and Conservation Status of the Freshwater Fishes in Sri Lanka. In: D.K. Weerakoon, S. Wijesundara (Eds.): The National Red List 2012 of Sri Lanka; Conservation status of the fauna and flora. Colombo, Sri Lanka: Ministry of Environment. P. 77-87.

Greenberg R., Bichier P., Sterling J. 1997. Bird populations in rustic and planted shade coffee plantations of eastern Chiapas, Mexico. Biotropica 29: 501-514. DOI: 10.1111/j.1744-7429.1997.tb00044.x

Gunatilleke C.V.S. 2007. A nature guide to the world's end trail, Horton Plains. Peradeniya: University of Peradeniya. 48 p.

Gunatilleke N., Pethiyagoda R., Gunatilleke S. 2008. Biodiversity of Sri Lanka. Journal of the National Science Foundation of Sri Lanka 36(25): 25-61.
Gunawardene N.R., Daniels D.A., Gunatilleke I.A.U.N., Gunatilleke C.V.S., Karunakaran P.V., Nayak G.K., Vasanthy G. 2007. A brief overview of the Western Ghats-Sri Lanka biodiversity hotspot. Current Science 93(11): 1567-1572.

He X., He K.S., Hyvönen J. 2016. Will bryophytes survive in a warming world? Perspectives in Plant Ecology, Evolution and Systematics 19: 49-60. DOI: 10.1016/j. ppees.2016.02.005

IPCC. 2013. Climate Change 2013: The Physical Science Basis. Contribution of Working Group I to the Fifth Assessment Report of the Intergovernmental Panel on Climate Change / T.F. Stocker, D. Qin, G.-K. Plattner, M. Tignor, S.K. Allen, J. Boschung, A. Nauels, Y. Xia, V. Bex and P.M. Midgley (Eds.). Cambridge, United Kingdom and New York, NY, USA: Cambridge University Press. 1535 p. DOI: 10.1017/CBO9781107415324

Iqbal M.C.M., Wijesundar D.S.A., Ranwala S.M.W. 2014. Climate change, invasive alien flora and concers for their management in Sri Lanka. Ceylon Journal of Science (Biological Science) 43(2): 1-15. DOI: 10.4038/cjsbs.v43i2.7321

Jayathunga R.D.S., Gunarathne K. 2016. Role of INDCs in the "blue green era" of Sri Lanka. NeelaHaritha: The Climate Change Magazine of Sri Lanka Inaugural volume: 17-20.

Jayawardene H.K.W.I., Jayewardene D.R., Sonnadara D.U.J. 2015. Interannual variability of precipitation in Sri Lanka Interannual variability of precipitation in Sri Lanka. Journal of the National Science Foundation of Sri Lanka 43: 75-82. DOI: 10.4038/ jnsfsr.v43i1.7917

Karunaratne W.A.I.P., Edirisinghe J.P. 2008. Diversity of bees at different altitude in the Knuckles forest reserve. Ceylon Journal of Science (Biological Science) 37(1): 61-72. DOI: $10.4038 /$ cjsbs.v37i1.496

Khaine I., Woo S.Y. 2015. An overview of interrelationship between climate change and forests. Forest Science and Technology 11(1): 11-18. DOI: 10.1080/21580103.2014.932718

Kotagama S.W., Bambaradeniya C.N.B. 2006. An overview of the wetlands of Sri Lanka and their conservation significance. In: National Wetland Directory of Sri Lanka. Colombo: IUCN Sri Lanka and Central Environmental Authority. P. 7-16.

Kottawa-Arachchi J.D. 2017. Biodiversity in central highland wetlands, a world heritage site in Sri Lanka. In: A.K.B. Prusty, R. Chandra, P.A. Azeez (Eds): Wetland Science: Perspectives From South Asia. New Delhi: Springer. P. 67-85. DOI: 10.1007/978-81-322-3715-0_4

Kottawa-Arachchi J.D., Gamage R.N. 2015a. Herpetofaunal richness in Lippakelle Tea Estate, Sri Lanka. Taprobanica 7(4): 268-271.

Kottawa-Arachchi J.D., Gamage R.N., Jayathilake G.G. 2015b. Vertebrate diversity and conservation aspects in 
manmade habitats in Mattakelle Tea Estate, Sri Lanka. WildLanka 3(3): 148-162.

Lenoir J., Gégout J.C., Marquet P.A., de Ruffray P., Brisse H.A. 2008. A significant upward shift in plant species optimum elevation during the 20th century. Science 320: 1768-1771. DOI: 10.1126/science.1156831

Manamendra-Arachchi K., Meegaskumbura M. 2012. The taxonomy and conservation status of amphibians in Sri Lanka. In: D.K. Weerakoon, S. Wijesundara (Eds.): The National Red List 2012 of Sri Lanka; Conservation status of the fauna and flora. Colombo, Sri Lanka: Ministry of Environment. P. 88-98.

Manamendra-Arachchi K., Pethiyagoda R. 2005. The Sri Lankan shrub-frogs of the genus Philautus Gistel, 1848 (Ranidae: Rhacophorinae), with description of 27 new species. Raffles Bulletin of Zoology Suppl. 12: 163-303.

Marambe B., Pushpakumara G., Silva P., Weerahewa J., Punyawardena R. 2013. Vulnerability of homegardens in Sri Lanka to climate change and its impact on household food security with special reference to tree crop diversity. In: H.P.M. Gunasena, J.M.T.D. Everard, C.S. Ranasinghe, A.D. Nainanayake (Eds.): Abstracts - International conference on climate change impacts and adaptations for food and environmat security. Lunuwila, Sri Lanka: Coconut Research Institute. P. 24.

Matos M.C.B., Sousa-Souto L., Almeida R.S., Teodoro A.V. 2013. Contrasting patterns of species richness and composition of solitary wasps and bees (Insecta : Hymenoptera) according to land-use. Biotropica 45(1): 73-79. DOI: 10.1111/j.1744-7429.2012.00886.x

McMahon S.M., Harrison S.P., Armbruster W.S., Bartlein P.J., Beale C.M., Edwards M.E., Kattge J., Midgley G., Morin X., Prentice I.C. 2011. Improving assessment and modelling of climate change impacts on global terrestrial biodiversity. Trends in Ecology and Evolution 26(5): 249-259. DOI: 10.1016/j.tree.2011.02.012

Meegaskumbura M., Meegaskumbura S., Bowatte G., Manamendra-Arachchi K., Pethiyagoda R., Hanken J., Schneider C.J. 2010. Taruga (Anura: Rhacophoridae), a new genus of foam-nesting tree-frogs endemic to Sri Lanka. Ceylon Journal of Science (Biological Sciences) 39(2): 75-94. DOI: 10.4038/cjsbs.v39i2.2995

Miththapala S. 2015. Conservation revisited. Ceylon Journal of Science (Biological Science) 44(2): 1-26. DOI: 10.4038/cjsbs.v44i2.7347

MOE. 2010. Biodiversity and ecosystem services: Sector vulnerability profile. In: Strengthening Capacity for Climate Change Adaptation: ADB TA 7326 (SRI). Sri Lanka: Ministry of Environment; Climate Change Secretariat. P. 1-90.

MOE. 2011. Sri Lanka's second national communication on climate change. Sri Lanka: Ministry of Environment; Climate Change Secretariat. 160 p.

MOE 2012. The National Red List 2012 of Sri Lanka; Conservation status of the fauna and flora. Colombo, Sri Lanka: Ministry of Environment. 451 p.
MOERE. 2014. Butterfly conservation action plan of Sri Lanka. Colombo, Sri Lanka: Biodiversity secretariat, Ministry of Environment and Renewable Energy. 101 p.

MOMDE. 2017. Sri Lanka's Forest Reference Level submission to the UNFCCC; Sri Lanka UN-REDD Programme. Sri Lanka: Ministry of Mahaweli Development and Environment. 32 p.

Myers N., Mittermeier R.A., Mittermeier C.G., da Fonseca G.A.B., Kent J. 2000. Biodiversity hotspots for conservation priorities. Nature 403: 853-858. DOI: $10.1038 / 35002501$

Nawaratne D.K. 1992. A survey of drought damage to tea in the Ratnapura region. Tea Bulletin 12: 34-42.

Peiris T.S.G., Hansen J.W., Zubair L. 2008. Use of seasonal climate information to predict coconut production in Sri Lanka. International Journal of Climatology 28: 103110. DOI: 10.1002/joc. 1517

Perera W.P.N., Bambaradeniya C.N.B. 2006. Species richness, distribution and conservation status of butterflies in Sri Lanka. In: C.N.B. Bambaradeniya (Ed.): Fauna of Sri Lanka: Status of taxonomy, research and conservation. Colombo: The World Conservation Union, Sri Lanka \& Government of Sri Lanka. P. 53-64.

Pethiyagoda R., Meegaskumbura M., Maduwage K. 2012a. A synopsis of the South Asian fishes referred to Puntius (Pisces: Cyprinidae). Ichthyological Exploration of Freshwaters 23(1): 63-95.

Pethiyagoda R. 2012b. Conservation. In: Horton Plains; Sri Lanka's Cloud-Forest National Park. Colombo: Wildlife Heritage Trust. P. 297-310

Poorten G. van der. 2012. The taxonomy and conservation status of the butterflies of Sri Lanka. In: D.K. Weerakoon, S. Wijesundara (Eds.): The National Red List 2012 of Sri Lanka; Conservation status of the fauna and flora. Colombo, Sri Lanka: Ministry of Environment. P. 26-41.

Poorten N. van der., Conniff K. 2012. The taxonomy and conservation of the Dragonfly Fauna (Insecta: Odonata) of Sri Lanka. In: D.K. Weerakoon, S. Wijesundara (Eds.): The National Red List 2012 of Sri Lanka; Conservation status of the fauna and flora. Colombo, Sri Lanka: Ministry of Environment. P. $1-10$.

Potts S.G., Biesmeijer J.C., Kremen C., Neumann P., Schweiger O., Kunin W.E. 2010. Global pollinator declines: trends, impacts and drivers. Trends in Ecology and Evolution 25(6): 345-353. DOI: 10.1016/j.tree.2010.01.007

Premalal K.H.M.S., Punyawardena B.V.R. 2013. Occurrence of extream climatic events in Sri Lanka. In: H.P.M. Gunasena, J.M.T.D. Everard, C.S. Ranasinghe, A.D. Nainanayake (Eds.): Abstracts - International conference on climate change impacts and adaptations for food and environmat security. Lunuwila, Sri Lanka: Coconut Research Institute. P. 24 
Priyadarshana M. 2016. Landsnails are susceptible to climate change. NeelaHaritha: The Climate Change Magazine of Sri Lanka Inaugural volume: 131.

Punchihewa R.W.K. 2013. Pollinators conservation action plan of Sri Lanka. Sri Lanka: Biodiversity Secretariat, Ministry of Environment. 64 p.

Pushpakumara D.K.N.G., Marambe B., Silva G.L.L.P., Weerahewa J., Punyawardena B.V.R.A. 2012. A review of research on homegardens in Sri lanka: the status, importance and future perspective. Tropical Agriculturist 160: 55-125.

Rajakaruna R.S., Samarawickrama V.A.M.P.K., Ranawana K.B. 2007. Amphibian declines and possible etiologies: the case for Sri Lanka. Journal of the National Science Foundation of Sri Lanka 35: 3-8.

Ranasinghe P.N., Fernando G.W.A.R., Wimalasena M.D.N.R., Siriwardana Y.P.S. 2009. Dieback in tropical montane forests of Sri Lanka: anthropogenic or natural phenomenon? Journal of Geological Society of Sri Lanka 13: 23-45.

Ranasinghe C.S. 2013. Impact of climate change on coconut and identification of adaptation measures with special emphasis on reproductive development. In: H.P.M. Gunasena, J.M.T.D. Everard, C.S. Ranasinghe, A.D. Nainanayake (Eds.): Abstracts - International conference on climate change impacts and adaptations for food and environmat security. Lunuwila, Sri Lanka: Coconut Research Institute. P. 32.

Ranil R.H.G., Pushpakumara D.K.N.G. 2012. Taxonomy and conservation status of Pteridophyte flora of Sri Lanka. In: D.K. Weerakoon, S. Wijesundara (Eds.): The National Red List 2012 of Sri Lanka; Conservation status of the fauna and flora. Colombo, Sri Lanka: Ministry of Environment. P. 148-164.

Ruklani N.C.S., Rubasinghe S.C.K., Long D.G. 2015. Morphological diversity of complex thalloid liverwort genera of Sri Lanka. Ceylon Journal of Science (Biological Science) 44(2): 27-44. DOI: 10.4038/ cjsbs.v44i2.7348

Sheikh M.M., Manzoor N., Ashraf J., Adnan M., Collins D., Hameed S., Jayasinghearachchi D., Kothawale D.R., Premalal K.H.M.S., Revadekar J.V. 2014. Trends in extreme daily rainfall and temperature indices over South Asia. International Journal of Climatology 35: 1625-1637. DOI: 10.1002/joc.4081

Toledo M., Poorter L., Pena-Claros M., Alarcon A., Balcazar J., Leano C., Licona C., Lianque O., Vroomans V., Zuidema P., Bongers F. 2011. Climate is a stronger driver of tree and forest growth rates than soil and disturbance. Journal of Ecology 99: 254-264. DOI: 10.1111/j.1365-2745.2010.01741.x

UNESCO. 2010. Central Highlands of Sri Lanka. Report of the decisions adopted by the World Heritage Committee at its 34th session. WHC-10/34.COM/20.

UNFCC. 1992. The United Nations framework convention on climate change. Available at: https://unfccc.int/ resource/docs/convkp/conveng.pdf (Retrieved on July 8, 2017).

Wagner F., Rossi V., Aubry-Kientz M., Bonal D., Dalitz H., Gliniars R., Stahl C., Trabucco A., Hérault B. 2014. Pan-tropical analysis of climate effects on seasonal tree growth. PLoS ONE 9(2): e92337. DOI: 10.1371/ journal.pone.0092337

Wanger T.C., Saro A., Iskandar D.T., Brook B.W., Sodhi N.S., Clough Y., Tscharntke T. 2009. Conservation value of cacao agroforestry for amphibians and reptiles in South-East Asia: combining correlative models with follow-up field experiments. Journal of Applied Ecology 46: 823-832. DOI: 10.1111/j.13652664.2009.01663.x

Weerakoon W.M.W. 2013. Impact of climate change on food security in Sri Lanka. In: H.P.M. Gunasena, J.M.T.D. Everard, C.S. Ranasinghe, A.D. Nainanayake (Eds.): Abstracts - International conference on climate change impacts and adaptations for food and environmat security. Lunuwila, Sri Lanka: Coconut Research Institute. P. 30.

Wickremasinghe H. 2016. Possible impact of drought on Nannophrys ceylonensis. NeelaHaritha: The Climate Change Magazine of Sri Lanka Inaugurate volume: 132.

Wijeratne M.A. 1996. Vulnerability of Sri Lankan tea plantations to global climate-change. Water, Air and Soil Pollution 92: 87-94. DOI: 10.1007/ BF00175555

Wijeratne M.A., Anandacoomaraswamy A., Amarathunga M.K.S.L.D., Ratnasiri J., Basnayake B.R.S.B., Kalra N. 2007a. Assessment of impact of climate change on productivity of tea (Camellia sinensis L .) plantations in Sri Lanka. Journal of the National Science Foundation of Sri Lanka 35(2): 119-126.

Wijeratne M.A., Chandrapala L. 2013. Analysis of rainfall and temperature in tea growing agro-ecological regions and assessment of vulnerability of tea plantations in Sri Lanka to climate change. Sri Lanka Journal of Tea Science 78(1/2): 42-45.

Williams P.H., Araújo M.B., Rasmont P. 2007. Can vulnerability among British bumblebee (Bombus) species be explained by niche position and breadth? Biological Conservation 138(3-4): 493-505. DOI: 10.1016/j.biocon.2007.06.001

Yakandawala D. 2012. Present status of fresh water aquatic flora in Sri Lanka. In: D.K. Weerakoon, S. Wijesundara (Eds.): The National Red List 2012 of Sri Lanka; Conservation status of the fauna and flora. Colombo, Sri Lanka: Ministry of Environment. P. 186-196.

Yatawatte S.T. 1992. A survey of drought damage to tea in the mid country in 1992. Tea Bulletin 12: 8-27.

Zubair L., Yahiya Z., Agalawatte P., Lokuhetti R. 2016. The El Niño event of 2015/16 in Sri Lanka Predictions, Preparedness, Communication and Impacts. NeelaHaritha: The Climate Change Magazine of Sri Lanka Inaugurate volume: 40-46. 


\title{
ВЛИЯНИЕ ИЗМЕНЕНИЯ КЛИМАТА НА БИОРАЗНООБРАЗИЕ И ЭКОСИСТЕМЫ ШРИ ЛАНКИ: ОБЗОР
}

\author{
Дж. Дананжайа Коттава-Араччи, Мадавала А. Виджератне \\ Институт исследований чая, Шри Ланка \\ e-mail: jeevan1188@yahoo.com, jeevank@tri.lk
}

\begin{abstract}
Воздействие изменения климата сказывается на всех аспектах и секторах экосистем, охватывая флору, фауну и окружающую среду. Шри-Ланка считается уязвимой малой островной страной, которая подвергается серьезной угрозе от последствий изменения климата. Наиболее глубокие последствия изменения климата в Шри-Ланке коснутся сельского хозяйства и безопасности продовольствия, водных ресурсов и прибрежных ресурсов, изменений в биоразнообразии и здоровья человека. Биоразнообразие Шри-Ланки имеет важное значение как в региональном, так и в глобальном масштабе, поскольку эта территория имеет самую высокую плотность видов цветущих растений, амфибий, рептилий и млекопитающих. Различные экосистемы Шри-Ланки предоставляют множество услуг, которые имеют значительную экономическую ценность и играют решающую роль в предоставлении товаров и экосистемных услуг. В последующих разделах, посвященных конкретным аспектам биоразнообразия лесов, пресноводных водно-болотных угодий, прибрежных и морских систем, сельскохозяйственных систем более подробно рассматриваются экосистемные услуги и биоресурсы. Утрата и фрагментация местообитаний, инвазионные чужеземные виды, обезлесение и деградация лесов, проекты в области развития, загрязнение окружающей среды и изменение климата (глобальное потепление) являются основными угрозами для биоразнообразия страны. Воздействие изменения климата на окружающую среду приводит к сокращению распространения и обилия видов, особенно эндемиков, что может даже привести к их исчезновению в глобальном масштабе. Внедрение различных политик и руководящих принципов в отношении окружающей среды является хорошим признаком сохранения экосистем и биологического разнообразия. Правительство Шри-Ланки осуществляет различные экологические проекты, направленные на сокращение обезлесения и деградации экосистем. Политики и меры, уже разработанные в рамках таких инициатив, несомненно, сохранят естественные места обитания для видов растений и животных. Но недостаточно лишь ресурсов развивающихся стран, обладающих многими экономическими проблемами, и средств и экспертных знаний, доступных для мониторинга последствий изменения климата и сохранения биоразнообразия.
\end{abstract}

Ключевые слова: засуха, количество осадков, наводнение, низинный тропический лес, сельское хозяйство, угрожаемые виды, утрата видов, центральные высокогорья 